\title{
Bibliografia historii wychowania, szkolnictwa i myśli pedagogicznej w Polsce za rok 2002 (z uzupelnieniami za lata poprzednie)
}

Bibliografia rejestruje druki zwarte, artykuły z czasopism i prac zbiorowych opublikowane w 2002 roku oraz te, które nie znalazły się w bibliografiach za rok 2001 i 2000, opublikowanych w „Biuletynie Historii Wychowania”. Pozycje w bibliografii ułożone zostały według podanego niżej schematu.

I. Bibliografie

II. Rozwój oświaty, wychowania i myśli pedagogicznej

1. Opracowania ogólne

2. Okres do 1795 roku

3. Okres $1795-1918$

4. Okres $1918-1939$

5. Okres $1939-1945$

6. Okres $1945-1989$

7. Okres $1990-2002$

8. Oświata polonijna

III. Dzieje szkół różnych stopni

1. Szkoły podstawowe i zakłady wychowawcze

2. Szkoły ogólnoksztalcące

3. Szkoły zawodowe

4. Zakłady kształcenia nauczycieli (z wyjątkiem szkół wyższych)

5. Szkoły wyższe

IV. Biografie

1. Zbiory życiorysów

2. Poszczególne biografie

V. Dzieje oświaty pozaszkolnej

1. Oświata dorosłych

2. Biblioteki

VI. Dzieje ruchu nauczycielskiego

1. Opracowania ogólne

2. Pamiętniki nauczycieli

VII. Organizacje młodzieżowe

\section{WYKAZ SKRÓTÓW CZASOPISM I WYDAWNICTW CIAGŁYCH}

Acta Univ. N. Copernici - Acta Universitatis Nicolai Copernici

Acta Univ. Wratislaviensis - Acta Univeristatis Wratislaviensis

Annales Univ. M. Curie-Skłodowska - Annales Universitatis Mariae Curie-Skłodowska Archiwa, Bibl. i Muzea Kośc. - Archiwa, Biblioteki i Muzea Kościelne Archiwum Hist. i Filoz. Med. - Archiwum Historii i Filozofii Medycyny Ateneum Kapt. - Ateneum Kapłańskie 
Białoruskie Zesz. Hist. - Białoruskie Zeszyty Historyczne

Biul. IPN - Biuletyn Instytutu Pamięci Narodowej

Biul. Nauk. Uniw. Warmińsko Mazurskiego - Biuletyn Naukowy Uniwersytetu Warmińsko-Mazurskiego w Olsztynie

Biul. Wojsk. Służby Archiw. - Biuletyn Wojskowej Służby Archiwalnej

Forum Oświat. - Forum Oświatowe

Kaliskie Studia Teol. - Kaliskje Studia Teologiczne

Kieleckie Studia Bibliol. - Kielcekie Studia Bibliologiczne

Kutnowskie Zesz. Regionalne - Kutnowskie Zeszyty Regionalne

Kwart. Hist. - Kwartalnik Historyczny

Kwart. Hist. Nauki i Techn. - Kwartalnik Historii Nauki i Techniki

Lubelski Roczn. Pedagog. - Lubelski Rocznik Pedagogiczny

Łódzkie Studia Teol. - Łódzkie Studia Teologiczne

Mazowieckie Studia Humanist. - Mazowieckie Studia Humanistyczne

Nadwarciański Roczn. Hist.-Archiw. - Nadwarciański Rocznik Historyczno-Archiwalny

Pamiętn. Cieszyński - Pamiętnik Cieszyński

Pamiętn. Teatralny - Pamiętnik Teatralny

Piotrkowskie Studia Pedagog. - Piotrkowskie Studia Pedagogiczne

Piotrkowskie Zesz. Hist. - Piotrkowskie Zeszyty Historyczne

Prace Nauk. UŚ w Katowicach - Prace Naukowe Uniwersytetu Ślaskiego w Katowicach

Podlaski Kwart. Kult. - Podlaski Kwartalnik Kulturalny

Przegl. Hist.-Ośw. - Przegląd Historyczno-Oświatowy

Przegl. Hist.-Wojsk. - Przeglad Historyczno-Wojskowy

Przegl. Polonijny - Przegląd Polonijny

Przegl. Prawosławny - Przegląd Prawosławny

Przegl. Zachodniopomorski - Przeglad Zachodniopomorski

Roczn. Bibl. Nauk. PAU i PAN w Krakowie - Rocznik Biblioteki Naukowej PAU i PAN w Krakowie

Roczn. Gdański - Rocznik Gdański

Roczn. Hist.-Archiw. - Rocznik Historyczno-Archiwalny

Roczn. Kaliski - Rocznik Kaliski

Roczn. Kałuszyński - Rocznik Kałuszyński

Roczn. Komisji Nauk Pedagog. - Rocznik Komisji Nauk Pedagogicznych

Roczn. Lubuski - Rocznik Lubuski

Roczn. Łódzki - Rocznik Łódzki

Roczn. Mazowiecki - Rocznik Mazowiecki

Roczn. Mielecki - Rocznik Mielecki

Roczn. Przemyski - Rocznik Przemyski

Roczn. Rymanowa Zdroju - Rocznik Rymanowa Zdroju

Roczn. Tarnowski - Rocznik Tamowski

Roczn. Toruński - Rocznik Toruński

Roczniki Humanist. - Roczniki Humanistyczne

Studia Hist. - Studia Historyczne

Studia i Mater. Polonist. - Studia i Materiały Polonistyczne

Śląski Kwart. Hist. Sobótka - Śląski Kwartalnik Historyczny Sobótka

Teki Archiw. - Teki Archiwalne

Zapiski Hist. - Zapiski Historyczne

Zesz. Chorzowskie - Zeszyty Chorzowskie

Zesz. Kwidzyńskie - Zeszyty Kwidzyńskie

Zesz. Nauk. AON - Zeszyty Naukowe Akademii Obrony Narodowej

Zesz. Staszicowskie - Zeszyty Staszicowskie 


\section{BIBLIOGRAFIE}

1. BIBLIOGRAFIA prac magisterskich i dyplomowych obronionych w Instytucie Pedagogiki [Uniwersytetu Rzeszowskiego] w latach 1974/75 - 1995/96. Oprac. i red. Janusz Homplewicz, Andrzej Meissner. Rzeszów 2002 Wydaw. Uniw. Rzeszowskiego ss. 201.

2. BIBLIOGRAFIA publikacji pracowników WSP w Rzeszowie za lata 1997-2001. Materiały zebrały i oprac. Stanisława Mach, Krystyna Serwatko. Rzeszów 2002 Wydaw. Uniw, Rzeszowskiego ss. 917.

3. MISZCZUK Marian: Bibliografia emigracyjnej i polonijnej prasy harcerskiej 1914-2001. Warszawa 2002 Tomiko ss. 157, il., sum.

4. TOBOLSKA Urszula: Bibliografia szkolnictwa i oświaty na Dolnym Śląsku 1976-1999. Wroclaw 2002 Pracownia Metodyczna Dolnośląskich Szkół Medycznych przy Medycznym Studium Zawodowym nr 1 ss. 268. Dolnośląska Bibl. Pedagog. Wrocław.

5. UNIWERSYTET Warszawski 1870 - 1915. Materiały bibliograficzne. Cz. 1. Oprac. Jadwiga Krajewska, Anna Bednarz. Warszawa 2002 Wydawnictwa UW ss. 499, nlb. 1. Bibl. Uniwersytecka w Warszawie.

\section{ROZWÓJ OŚWIATY, WYCHOWANIA I MYŚLI PEDAGOGICZNEJ}

\section{Opracowania ogólne}

6. BARTNICKA Kalina, Szybiak Irena: Zarys historii wychowania. Warszawa 2001 Wydaw. Akademickie „ŻAK ss. 220 , nlb. 1.

7. BARTNICKI Roman: Fundamentalne zasady funkcjonowania uniwersytetów. Średniowieczne wzorce i współczesne dylematy. Saeculum Christianum. R. 8: 2001 nr 1 s. $201-217$, rés.

M.in. Akademia Krakowska.

8. BENDOWSKA Dorota: Działalność oświatowa i patriotyczna OO. Bernardynów z klasztoru kalwaryjskiego w przeszłości. W: Kalwaria Zebrzydowska - polska Jerozolima skarbem Kościoła i narodu polskiego. Pod red. Czesława Gnieckiego. Kalwaria Zebrzydowska 2002 s. $463-466$.

XVII-XX w.

9. CIEŚLA Marian: Szkic historyczny szkół w Suszcu. Suszec 2002 Urząd Gminy ss. 121, il.

K. Pszczyny, XVII - XX w.

10. DAWID Łucja: Literatura piękna na łamach „Miesięcznika Pedagogicznego" w latach 1892 - 1939. Szkic informacyjny. Prace Nauk. US w Katowicach. Nr 1978: Studia Bibliologiczne. T. 13: 2001 s. $62-72$, rez., sum.

11. DOMAGAŁA Jarosław, Leleń Andrzej: Ksztalcenie organistów diecezji płockiej w latach 1902 - 2002. Płock 2002 Płocki Inst. Wydawniczy ss. 96, il.

12. DZIEJE kształtowania się polskich instytucji oświatowych. Pod red. Edwarda A[lfreda] Mierzwy. Piotrków Trybunalski 2002 Nauk. Wydaw. Piotrkowskie ss. 350. Akad. Świętokrzyska im. J. Kochanowskiego. Filia w Piotrkowie Trybunalskim. Inst. Historii.

Treść: Mierzwa E. A.: Rys historyczny polskich instytucji oświatowych przed XVII wiekiem s. 9-27; Pelczar Roman: Kolegia szlacheckie (collegia nobilia) i ich rola w oświacie Rzeczypospolitej XVIII wieku s. 29-42; Włodarski Józef: Wpływ Oświecenia na wyższe szkoły jezuickie w Wilnie (ze szczególnym uwzględnieniem Collegium Nobilium 1740-1775) s. 43-59; Wróbel-Lipowa Krystyna: Działalność wydawnicza Uniwersytet Wileńskiego w latach 1803 - 1832 s. 61 - 67; Łysiak Anna: Organizacja i funkcjonowanje Gimnazjum w Krzemieńcu we wspomnieniach i relacjach pamiętnikarskich s. 69 - 78; Moklak Jarosław: Stanowisko posłów ruskich (ukraińskich) 
w Sejmie Krajowym galicyjskim wobec projektu ustanowienia Rady Szkolnej Krajowej (1866 r.) s. 79 -89; Stawiak-Ososińska Małgorzata: Szkoła akuszerek w Warszawie w latach 1802 - 1831 s. 91 - 108; Pękowska Marzena: Zakład Guchoniemych w Poznaniu i Zakład dla Niewidomych w Bydgoszczy (1832 - 1914). Stan i potrzeby badawcze s. 109-122; Szabat Barbara, Czapska Małgorzata: Kształtowanie się polskich, spolecznych instytucji oświatowych w guberni kieleckiej na początku XX wieku s. 123 -142; Kula Ewa: Nauczyciele męskich rządowych szkół średnich Królestwa Polskiego w latach 1862-1873 w świetle przepisów prawnych s. 143-157; Szmyt Andrzej: Wybitni nauczyciele Liceum krzemienieckiego s. 159-170; Ritter Anna: Z badań nad siecią rządowego szkolnictwa elementarnego ziemi piotrkowskiej w I połowie XIX wieku s. 171 - 197; Bednarzak-Libera Mirosława: Działalność Towarzystwa Szkoły Ludowej na obszarze monarchii austro-węgierskiej (poza Galicja) w latach $1891-1918$ s. 199-231; Białokur Marek: Powstanie i pierwsze lata działalności Towarzystwa Oświaty Narodowej na Rusi (1904 - 1909) s. 233 - 246; Sadowska Joanna: Nowy typ szkoły średniej - licea ogólnokształcace w II Rzeczypospolitej s. 247-263; Małolepszy Eligiusz: Działalność lokalnych struktur Państwowego Urzędu Wychowania Fizycznego i Przysposobienia Wojskowego w województwie lódzkim (1927-1939) s. 265-276; Florek Magdalena: Zawodowe szkolnictwo muzyczne województwa kieleckiego w świetle przepisów prawnych w latach 1945-1975 s. 277-292; Glowacki Albin: Dokonania Komitetu ds. Dzieci Polskich w ZSRR w dziedzinie wydawnictw edukacyjnych s. 293 - 306; Majewski Stanisław: Organizacja szkolnictwa średniego ogólnokształcacego w województwie kieleckim 1944 - 1975 s. 307 -330; Syrnyk Marek: Szkolnictwo ukraińskie w Polsce w okresie międzywojennym s. 331 - 340.

13. DZIEJE oświaty na Ziemi Łosickiej. Materiały z konferencji populamo-naukowej odbytej w Łosicach 29.05.2001 r. Pod red. Arkadiusza Indraszczyka. Warszawa 2002 Muzeum Historii Pol. Ruchu Lud. ss. 226, il.

Treść: Gmitruk Janusz: Od wydawcy s. 7-8; Indraszczyk A.: Wstęp s. 9-13; Cz. 1: Rozwój oświaty w regionie losickim: Gmitruk J.: Oświata dla ludu s. 17 -31; Dobrowolski Tomasz: Oświata na Ziemi Łosickiej w II polowie XIX wieku s. 32-65; Brzeziński Stanisław: Oświata na Ziemi Łosickiej w okresie międzywojennym s. 66-76; Bolesta Wojciech: Wybrane problemy szkolnictwa podstawowego w kosicach w latach 1956-1998 s. 77-92; Cz. 2: Dzieje szkół i placówek oświatowych w Łosicach: Sobieszuk Stanislaw: Szkoła Podstawowa nr 1 w Łosicach s. 95 - 108; Kobylińska Helena: Szkoła Podstawowa nr 2 w Losicach s. 109 - 114; Chojecki Ryszard: Liceum Ogólnokształcące w Łosicach (1944-2000) s. 115-131; Raczyński Michał: Zespół Szkół Zawodowych w Łosicach s. 132-139; Trelikowska Joanna: Zespół Szkół Rolnicze Centrum Kształcenia Ustawicznego w Losicach s. 140-147; Pawluk Jadwiga: Specjalny Ośrodek Szkolno-Wychowawczy w Eosicach s. 148 - 156; Czerko Anna: Biblioteka Pedagogicza w Łosicach s. 157 - 162; Jaszczuk Andrzej: Państwowa Szkoła Muzyczna I stopnia w Łosicach s. 163 - 164; Ludwiczuk Jan: Powiatowa Poradnia Wychowawczo-Zawodowa w Łosicach s. 165-168; Margraf Janina: Wychowanie przedszkolne w Łosicach w latach 1950 - 1999 s. 169 - 173; Bolesta Wojciech: Bursa szkolna w Łosicach s. 174-175; Wawryniuk Eugeniusz: Historia Oddziału ZNP w Losicach s. 176-186; Cz. 3: Biogramy, dokumenty, zdjęcia s. $187-225$

14. DZIEJE szkolnictwa i ruchu nauczycielskiego w Ostrowcu Świętokrzyskim i w okolicach w latach 1820 - 2000. Pod red. Mariana Banaszaka. Ostrowiec Świętokrzyski 2000 ZNP.O.KH ss. 187, nlb. 2. Zw. Nauczycielstwa Pol. Oddz. w Ostrowcu Świętokrzyskim. Komisja Hist.

Treść: Banaszek M.: Okres zaborów s. 7-40; Banaszek M.: Międzywojnie s. 41-60; Czapka Anna: Struktura i działalność zawodowego ruchu nauczycielskiego s. 61 -74; Banaszek M.: Wojna i okupacja niemiecka s. $75-85$; Banaszek M.: Okres powojenny s. 86-141; Banaszek M., Chałat Zdzisław: Kryzys ruchu zwiazkowego s. 142 - 146; Banaszek M.: Lata 1990 - 2000 s. 147-156; Borys Krystyna: Dalsze przeobrażenia w ruchu zawodowym pracowników oświaty i wychowania s. $157-162$.

15. DZIŚ i wczoraj edukacji polonistycznej. Ścieżki badawcze. Pod red. Anieli Ksiażek-Szczepanikowej, Marcina Wlazło. Szczecin 2002 Wydaw. Nauk US ss. 224, nlb. 1., sum. Uniw. Szczeciński. Rozprawy i Studia. T. 434.

16. EDUKACJA - państwo - naród w Europie Środkowej i Wschodniej XIX i XX w. Pod red. Aleksandry Bilewicz, Ryszarda Gładkiewicza, Stefanii Walasek. Wrocław 2002 Uniw. Wrocławski. Inst. edagogiki. Centrum Badań Śląskoznawczych i Bohemistycznych ss. 456, sum.

Z treści: Walasek S.: Szkolnictwo i oświata na ziemiach polskich w XIX i na początku XX wieku s. 13-19; Brynkus Józef: Polska świadomość narodowa w XIX wieku - perspektywy interpretacyjne s. 21 -33; Walewander Edward: Treści wychowawcze w nauczaniu parafialnym na ziemiach polskich w drugiej polowie XIX wieku s. 35-59; Wojtkiewicz-Rok Wanda: Organizacja szkolnictwa medycznego w Galicji Wschodniej w latach 1772 - 1872 s. 61 - 69; Kudła Lucyna: Młodzież galicyjskich gimnazjow wobec szkolnej polityki władz w okresie autonomii galicyjskiej (1867-1918) s. 71 - 83; Meissner Andrzej: Walka o świadomość narodową nauczycieli polskich w zaborze austriackim s. 85 - 94; Łuczyńska Barbara: Polityczne przesłanki udziału nauczycieli szkół średnich Galicji w ukraińskim ruchu odrodzenia narodowego s. 139-150; Rędziński Kazimierz: Akulturacyjna i integracyjna rola żydowskich szkół świeckich w Galicji na przelomie XIX-XX wieku s. 165-170; Pańko Grażyna: Gimnazja polskie w Cieszynie 
i Orlowej oraz ich rola w kształtowaniu świadomości narodowej Polaków w monarchii austro-węgierskiej (1895 - 1918) s. 171 - 176; Baron Roman: Z problematyki polskiej oświaty na pograniczu Śląska i Moraw. Działalność Towarzystwa Szkoły Ludowej na Kresach Ostrawskich na poczatku XX wieku s. 177-185; Krzanowski Adam: Budzenie się świadomości narodowej i państwowej na przykładzie pracy drużyn skautowych i harcerskich s. 187-201; Czapska Małgorzata: Sieć szkół średnich prywannych w Królestwie Polskim w latach 1833-1862 s. 203-218; Kula Ewa: Aktywność intelektualna nauczycieli uczących języka polskiego $\mathrm{w}$ męskich rządowych szkołach średnich Królestwa Polskiego w drugiej połowie XIX wieku s. 219-235; Stawiak-[Ososińska] Malgorzata: Rola kobiet w wychowaniu patriotycznym młodego pokolenia w Królestwie Polskim w okresie międzypowstaniowym s. 237 - 247; Wołczuk Janina: Rozprawki nauczycieli szkół Królestwa Polskiego jako element panoramy życia kulturalnego epoki paskiewiczowskiej s. 249-267; Gulczyńska Justyna: Wychowanie narodowe dziewczat polskich w zaborze pruskim na przełomie XIX i XX wieku s. 269-276; Sadowska Joanna: Ustawodawstwo jędrzejowiczowskie wobec szkolnictwa mniejszości narodowych w II Rzeczypospolitej s. 297 - 309; Meducka Marta: Szkolnictwo żydowskie w województwie kieleckim w latach 1918 - 1939 wobec dążeń narodowych mniejszości żydowskiej s. 311 -324; Pẹkowska Marzena: Żydowska Szkoła dla Gluchoniemych im. Izaaka Bardacha we Lwowie (1870-1939) s. 325-334; Sanojca Karol: Problem lojalności nauczycieli Ukraińców wobec państwa polskiego w okresie międzywojennym s. 335 - 341; Vaculik Jaroslav: Druga Rzeczpospolita i szkoła czeska na Wołyniu s. 343-351; Sapia-Drewniak Eleonora: Kursy dokształcajace na Ślasku Opolskim w okresie międzywojennym s. 353 - 358; Jaworski Paweł: Uniwersytety ludowe - skandynawski wzór w polskiej rzeczywistości 1900-2000 s. 401-413.

17. EDUKACJA historyczna a współczesność. Księga jubileuszowa dedykowana Profesorowi dr hab. Adamowi Suchońskiemu w czterdziestolecie pracy dydaktycznej i naukowej oraz z okazji siedemdziesiatych urodzin. Pod red. Barbary Kubis. Opole 2002 UO ss. 488, tabl. 1. Uniw. Opolski.

Z treści: Maternicki Jerzy: Problemy metodologiczne badań nad dziejami dydaktyki historii s. 165-178; Pobóg-Lenartowicz Anna: Edukacja historyczna w klasztorach kanoników regularnych w średniowieczu s. 179 - 189;Burda Bogumila: Język, przedmioty, podręczniki, metody nauczania w średnim szkolnictwie na Dolnym Ślasku w XVI wieku s. 191-200; Długosz Józef: Rady wychowawcze Jana Innocentego Petrycego dla I ordynata Ostrogskiego (11633) [Wladyslawa Dominika Zasławskiego] s. 201 - 205; Dorobisz Janusz: Peregrynacje i fundacje naukowe biskupa Jakuba Zadzika (1582-1642) s. 207-213; Kaczorowski Włodzimierz, Seredyka Jan: Instrukcje wychowawcze mieszczanina krakowskiego Jana Markiewicza (1613-1691) s. 215-220; Kulak Teresa: Z genezy miejskiego średniego szkolnictwa żeńskiego we Wroclawiu w drugiej połowie XIX wieku s. 221-230; Glimos-Nadgórska Anna: Rozkłady godzin i treści programowe realizowane w polskim szkolnictwie powszechnym województwa ślaskiego w latach $1922-1931$ s. 231-247; Centkowski Jerzy: Ostforschung a szkolna edukacja historyczno-polityczna w RFN w latach 1949 - 1990 s. 249-255; Rzońca Jan: Znaczenie historii małych ojczyzn dla umocnienia tożsamości regionalnej s. $263-275$; Świder Małgorzata: Oświata i szkolnictwo wyżzze w Unii Europejskiej s. $277-285$.

18. EDUKACJA wobec wielokulturowości. Księga jubileuszowa ofiarowana profesorowi Januszowi Sztumskiemu. Pod red. Marii Janukowicz i Kazimierza Rędzińskiego. Częstochowa 2002 Wydaw. WSP ss. 287, tabl. 2, il. Wyższa Szkoła Pedagog. w Częstochowie.

Z treści: Hellwig Jan: Kontrowersje wokół zwiazków Galicji i byłej Kongresówki z Wielkopolską po odzyskaniu niepodległości w 1919 roku (na przykładzie nauk o wychowaniu i szkolnictwa) s. 9 - 13; Walasek Stefania: Edukacja dzieci i dorosłych w spoleczeństwie wielokulturowym guberni wileńskiej w XIX i na początku XX w. s. 15- 19; Snoch Bogdan: Z tradycji kształcenia nauczycieli w Częstochowie w okresie II Rzeczypospolitej (szkic) s. 21 - 24; Rędziński K.: Szkolnictwo polskie w Małopolsce Wschodniej pod okupacja hitlerowska (1941-1944) s. 25-48; Suchmiel Jadwiga: Emarıcypacja dziewczą żydowskich z okresu monarchii Habsburgów oraz jej efektywność w edukacji uniwersyteckiej (na przykładzie Austrii i Galicji) s. 49-57; Szczygieł Miroslaw: Wkład rodziny Kronenbergów w rozwój szkolnictwa zawodowego w Królestwie Polskim na przelomie XIX i XX wieku s. 59-63; Nowakowska Izabela: Wielokulturowość w lódzkich szkołach średnich na przełomie XIX i XX wieku s. 73-78; Haratyk Anna: Uniwersytet Wakacyjny w Zakopanem jako jedno ze żródeł łączności i edukacji kulturalnej Polaków w okresie zaborów s. 79-84; Pawelec Lidia: Grzegorza Piramowicza poglądy na szkołę jako wspólnotę wychowawczą s. 85-91; Łapot Mirosław: Rola tearrow ludowych w krzewieniu idei wychowawczych w okresie pozytywizmu s. 93-102; Rędziński K.: Rys biograficzny [Janusz Sztumski] s. 275-277; Rędziński K.: Bibliografia ważniejszych publikacji Janusza Sztumskiego (w układzie chronologicznym) s. 278-281.

19. GAMULCZAK Franciszek: W trosce o ich los (1949-2002). Praca z dziećmi i młodzieżą z ograniczona sprawnościa ruchowa. Stalowa Wola-Konstancin 2002 Sztafeta ss. 312, tabl. 25. Specjalistyczne Centrum Rehabilitacji i Leczenia Schorzeń Narządu Ruchu „STOCKER” im. prof. Mariana Weissa w Konstancinie-Jeziornie.

20. GAWROŃSKA Ewa: Szkolnictwo muzyczne Torunia w latach 1921-1960. Toruń 2002 Wydaw. Adam Marszałek ss. 202, nlb. 1. 
21. GRZADZIELSKI Zbigniew: Z problemów opieki i kształcenia młodzieży żydowskiej w Częstochowie w latach 1912 -1939. W: Z dziejów Żydów w Częstochowie. Pod red. Zbigniewa Jakubowskiego; przy wspólpr. Stanisława Podobińskiego. Częstochowa 2002 s. 45-62.

22. GURYCKA Antonina: Korczakowskie inspiracje... Warszawa 2002 Scholar ss. 155, il. Szkice $\mathrm{z}$ historii pedagogiki.

23. JANKOWSKI Wojciech: Polskie szkolnictwo muzyczne. Geneza i ewolucja systemu. Warszawa 2002 AM ss. 117. Akad. Muzyczna im. F. Chopina oraz Centrum Edukacji Artystycznej.

24. KABZIŃSKA Łucja: Rola polskich Kongresów Pedagogicznych w latach 1894-1939 w ksztaltowaniu teoretycznych podstaw systemu edukacji narodowej. Forum Oświat. T. 1: 2002 s. $127-150$.

25. KARDYŚ Piotr: Apostołowie Słowian w podręcznikach do historii. Przegl. Hist.-Oświat. R. 45: 2002 z. $3 / 4$ s. $122-130$.

26. KROŚNICKA Józefa: Z dziejów oświaty i Zwiąku Nauczycielstwa Polskiego w powiecie gdańskim (1919-1980). Pruszcz Gdański 2002 Agni ss. 108, il.

27. KUDOWA. Zdrój, miasto i ludzie. Praca zbiorowa. Kom. red. Bronislaw Kamiński [i in.]. Kłodzko-Kudowa Zdrój 2002 Stow. na Rzecz Rozwoju Miasta ss. 592, tabl. 15, il.

Z tresci: Szkolnictwo i oswiata w Kudowie Zdroju: Czartowski Jerzy: Szkoła Podstawowa nr 1 w Kudowie Zdroju s. 352 -357; Kukasik Jerzy: Publiczna Szkoła Podstawowa nr 2 w Kudowie Zdroju s. 358-370; Gaździak Zygmunt: Publiczna Szkoła Podstawowa nr 3 w Kudowie Zdroju s. 371 - 379; Zagzil Roman: Publiczna Szkola Podstawowa nr 4 im. Stanisława Moniuszka s. 380-390; Dziubińska Barbara: Publiczne Gimnazjum w Kudowie Zdroju s. 391 - 406; Brodziak Roman: Liceum Ogólnokształcące im. Józefa Lompy. „Między dawnymi, a młodszymi laty..." s. 407-416; Rachuba Łucja: To już XXXX [sic!] lat Zespołu Szkół Zawodowych w Kudowie Zdroju s. 417-431; Charczuk Tatiana: Szkoła Podstawowa i Gimnazjum przy Szpitalu Rehabilitacyjnym Hematologicznym „Orlik" s. 432-436; Pawłowska Elżbieta: Zespół Szkół przy Szpitalu Uzdrowiskowym dla Dzieci "Jagusia” s. $437-441$; .

28. LANDAU-CZAJKA Anna: Co Alicja odkrywa po własnej stronie lustra. Życie codzienne, społeczeństwo, władza w podręcznikach dla dzieci najmłodszych 1785 - 2000. Warszawa 2002 Neriton; Inst. Historii PAN ss. 437, nlb. 1.

29. MERŻAN Ida: Dzieci - miłość moja, duma moja, troska moja. Wybór Marta Ciesielska, Olga Kierczyńska; przedm. Kazimierz Koźniewski. Warszawa 2002 Ezop ss. 278, tabl. 32, il. Z Kręgu Korczaka. Tematy, ludzie, dokumenty.

Artykuły bliskiej wspólpracowniczki Janusza Korczaka opublikowane w 1. 1937-1986.

30. MĘDRZECKI Włodzimierz: Młodzież wiejska na ziemiach Polski centralnej 1864-1939. Procesy socjalizacji. Warszawa 2002 DiG ss. 211. Inst. Historii PAN.

31. MICHALCZYK Jadwiga: Polska myśl dydaktyczna w zakresie geografii wobec osiagnięć wspólczesnych. Annales Univ. M. Curie-Skłodowska. Sec. B: Geographia, Geologia, Mineralogia et Petrographia. Vol. 54: 1999 s. 333-346, sum.

$\mathrm{XIX}-\mathrm{XX}$ w.

32. MOZOR Karol: Szkolnictwo katolickie w Cieszyńskim Wikariacie Generalnym 1770- 1925. Kraków 2002 Wydaw. Nauk. PAT ss. 312, tabl. 8, il., mapa, shrnut(, sum., Zsfg. Papieska Akad. Teol. w Krakowie. Wydz. Historii Kościoła. Rozprawy Doktorskie.

33. MOŻDŻEŃ Stefan I[gnacy]: Inspiracje katolickiej myśli wychowawczej w Polsce do połowy XX wieku. Kielce 2001 Wydaw. Akad. Świętokrzyskiej ss. 316.

Od początku dziejów.

34. MROZOWSKA Kamilla: Zarys dziejów wychowania w Polsce od XI do XX wieku. Podręcznik dla studentów wyższych szkół technicznych. Wyd. 2 uzup. Kraków 2002 Wydaw. PK ss. 87. Politech. Krakowska im. T. Kościuszki.

Wyd. 1. 1998. 
35. NAUCZYCIEL - opiekun - wychowawca (tradycje, teraźniejszość, nowe wyzwania). Pod red. Ryszarda Stankiewicza. Poznań-Zielona Góra 2002 Eruditus ss. 399, nlb. 1.

Treść: Stankiewicz R.: Nauczyciel w czasach II Rzeczypospolitej s. 13-84; Kochan Katarzyna: Nauczyciele edukacji wczesnoszkolnej w Polsce (1945-2000) s. 85-136; Kahl Edyta: Doskonalenie nauczycieli w Polsce (1945-2000) s. 137-239; Bartkowiak Edyta: O tradycyjnym i nowym pojmowaniu roli opiekuna-wychowawcy w Polsce (od przełomu XII/XIII do końca XX wieku) s. 243-299; Skafiriak Beata: Oczekiwania wobec opiekunów-wychowawców dzieci osieroconych a ich kształcenie, doksztalcanie i doskonalenie w Polsce (1945 - 2000) s. 300-363; Zukiewicz Arkadiusz: Pracownicy socjalni w służbie pomocy spolecznej s. 367-400.

36. NAWROT Dariusz: Z dziejów kształcenia oficerów Polskiej Marynarki Wojennej. Zesz. Nauk. AON. $2000 \mathrm{nr} 1$ s. 276-295, sum.

$\mathrm{XX}$ w.

37. NIEZGODA Cecylian: Działalność edukacyjna Sióstr Klarysek w Krakowie i Starym Sączu. W Nurcie Franciszkańskim. T. 11: 2002 s. $125-146$, sum.

XVIII - XX w.

38. OD NARODZIN do wieku dojrzałego. Dzieci i młodzież w Polsce. Praca zbiorowa. Cz. I: Od średniowiecza do wieku XVIII. Pod red. Marii Dabrowskiej i Andrzeja Klondera. Warszawa 2002 IAiE PAN ss. 324, tabl. 8, il., sum. Inst. Archeologii i Etnologii PAN.

Treść: Sowina Urszula: Wdowy i sieroty w świetle prawa w miastach Korony w późnym średniowieczu i wczesnej nowożytności s. 15-28; Kizik Edmund: Kindelbier. Chrzciny w miastach Prus Królewskich w XVI - XVIII wieku s. 29-54; Sierocka-Pośpiech Maria: Urodzenia i chrzty w siedemnastowiecznej Warszawie (czas i miejsce) s. 55 - 66; Turska Krystyna: Źródła do ubiorów dzieci Jagiellonów w XV i poczatku XVI wieku s. 67-80; Kopczyński Michat: Rodzinne gniazdo? Mieszkańcy szlacheckich dworów w XVII i XVIII wieku s. 81 - 95; Żoładź-Strzelczyk Dorota: Wychowanie dziecka w świetle staropolskiej teorii pedagogicznej s. 96-108; Glówka Dariusz: Staropolscy kaznodzieje o wychowaniu dzieci s. 109-114; Kowalczyk Jerzy: Wychowanie hetmanica Tomasza Zamoyskiego w świetle wydatków z lat $1605-1608$ s. 115-128; Augustyniak Urszula: Wychowanie młodych Radziwilłów na dworze birżańskim w XVII wieku s. 129-148; Zielińska Teresa: Programy i metody pedagogiczne związane z osoba Hieronima Floriana Radziwilła (1715-1769). Przyczynek do dziejów edukacji w Rzeczypospolitej epoki saskiej s. 149 - 162; Pośpiech Andrzej: Rzeczy dziecięce w inwentarzach pośmiertnych szlachty wielkopolskiej w XVII wieku s. 163 - 166; Surdacki Marian: Dzieci porzucone w spoleczeństwach dawnej Europy i Polski s. 169 - 185; Słoń Marek: Średniowieczny szpital dziecięcy we Wrocławiu s. 186-191; Piwowarczyk Dariusz: Funkcje i ceremoniał rycerskiego pasowania na ziemiach polskich (XI - XVIII wiek) s. 192-217; Boroda Krzysztof: Późnośredniowieczne krakowskie kolegia studenckie s. 218-230; Trzoska Jerzy: Sytuacja formalno-prawna i materialna oraz perspektywy awansu zawodowego uczniów w cechach gdańskich w drugiej połowie XVII i w XVIII wieku s. 231 - 242; Karpiński Andrzej: Wrew prawu i moralności. Dziecko jako ofiara przemocy, agresji i deprawacji w miastach polskich w XVI-XVIII wieku s. 243 -266; Wrzesińska Anna, Wrzesiński Jacek: Pochówki dzieci najmłodszych Infas I na wczesnośredniowiecznym cmentarzysku w Dziekanowicach s. 269-284; Żerek-Kleszcz Hanka: Śmierć dziecka w kulturze staropolskiej s. 285-300; Dziubkowa Joanna: Wizerunek dziecka na portrecie trumiennym s. 301-324.

39. POBÓG-LENARTOWICZ Anna: „Kultura edukacyjna na Górnym Śląsku” z cyklu: Kultura i Europy Środkowej, Zabrze $15-16$ XI 2001 r. Sląski Kwart. Hist. Sobótka. R. 47: 2002 nr 2 s. $288-289$.

40. RODZINNE i pozarodzinne środowiska wychowawcze. Szkice historyczno-pedagogiczne. Pod red. Aleksandry Siedlaczek-Szwed i Iwony Wagner. Częstochowa 2002 Wydaw. WSP ss. 278, nlb. 6.

Z treści: Kahl Edyta: Wychowanie w rodzinie szlacheckiej w poglądach i praktyce pedagogicznej doby Renesansu s. 17-29; Szwed Robert: Rodzina szlachecka po utracie niepodleglości i w Księstwie Warszawskim (na przykladzie Fredrów) s. 31 -49; Złotkowski Dariusz: Obraz szkoły wiejskiej schylku XIX wieku, w relacjach młodych nauczycieli s. 61 -78; Siedlaczek-Szwed A.: Geneza akcji świetlicowej w Polsce okresu międzywojennego s. 79 - 100; Wróblewska Teresa: Wielki humanista, mistrz, wychowawca, nauczyciel i badacz prof. Tadeusz Stefan Zieliński (14 IX $1859-14$ V 1944) s. 101-113.

41. RODZOŚ Jolanta: Rozwój polskiej dydaktyki geografii na tle myśli pedagogicznej XX wieku. Annales Univ. M. Curie-Skłodowska. Sec. B: Geographia, Geologia, Mineralogia et Petrographia. Vol. 54: 1999 s. $311-331$, sum,

42. ROGOZIŃSKA Anna: Szkoły sióstr urszulanek w Tarnowie w latach 1877 - 1953. Lublin 2002 Tow. Nauk. KUL. ss. 360, nlb. 2, il., sum. Źródła i Monografie. [T.] 233. 
43. RONIKIER Jerzy: Mit i historia. Mitotwórcze funkcje podręczników szkolnych. Kraków 2002 Wydaw. UJ ss. 174, nlb. 1, sum., rés.

$\mathrm{XX}$ w.

44. RYBAK Arkadiusz: Z dziejów oświaty na terenie Strzemieszyc Małych: 1820 - 2000. Dąbrowa Górnicza 2002 Muzeum Miej. „Sztygarka” ss. 86, nlb. 2, il.

Obecnie dzielnica Dąrowy Górniczej.

45. SADOWSKA Joanna: Dzieje kształtowania się poiskich instytucji oświatowych. Konferencja naukowa, Piotrków Trybunalski, 28 - 29 czerwca 2002 r. Studia Podlaskie. T. 12: 2002 s. $431-434$.

46. SMOTER Wojciech: Szkolnictwo w Dąbrowie i Szarowie - dzieje znane i nieznane. Dąbrowa-Szarów 2002 Nakł. autora; przy współudz. Urzędu Gminy w Kłaju ss. 109, nlb. 1, tabl. 8, il.

$\mathrm{XIX}-\mathrm{XX}$ w.

47. SZKOLNICTWO prawosławne w Rzeczypospolitej. Pod red. nauk. Antoniego Mironowicza, Urszuli Pawluczuk, Piotra Chomika. Białystok 2002 Zakł. Historii Kultury Pogranicza Inst. Socjologii Uniw. w Białymstoku; Bractwo Prawosławne św. św. Cyryla i Metodego ss. 256.

Z treści: Mironowicz A.: Wprowadzenie s. 5-6; Mironowicz A.: Szkolnictwo prawosławne w Rzeczypospolitej s. 18-39; Chynczewska-Hennel Teresa: Akademia Kijowsko-Mohylańska s. 40-54; Kempa Tomasz: Akademia Ostrogska s. 55 -79: Utrutko Ludmiła: Szkoly prawosławne w rozumieniu Sylwestra Kossowa s. 80-91; Surynowicz Halina: Szkolnictwo cerkiewne na Grodzieńszczyźnie w XIX wieku s. 106-138; Sosna Grzegorz: Szkoła monasteru krasnostockiego s. 139-146; Pawluczuk U.: Seminaria duchowne w Krzemieńcu i w Wilnie s. 147-166; Tofiluk Jerzy: Szkolnictwo prawosławne w Polsce powojennej s. 167-178; Malaszewski Dariusz: Nauczanie religii prawoslawnej na obszarze diecezji wroclawsko-szczecíńskiej w latach 1945-1970 s. 179-200; Zieniuk Jan: Kształcenie, dokształcanie i doskonalenie nauczycieli religii prawosławnej w latach 1990-2000 s. $201-213$; Matwiejuk Jarosław: Podstawy prawne nauczania religii prawosławnej w Rzeczypospolitej Polskiej s. 214-236; Chomik P.: Elementy dydaktyczne w poezji maryjnej jako forma kultu cudownych ikon Matki Bożej w Wielkim
Księstwie Litewskim s. 237-255.

48. SZKOŁA i nauczyciel w polskiej beletrystyce pozytywizmu, Mlodej Polski i dwudziestolecia międzywojennego. Materiały pomocnicze do kształcenia historii wychowania. Pod red. Tadeusza Jałmużny. Łódź 2002 Wydaw. Uniw. Łódzkiego ss. 85.

49. SZYLAR Anna: Działalność oświatowa benedyktynek sandomierskich w latach 1616-1865. Lublin 2002 Tow. Nauk. Katol Uniw. Lubelskiego ss. 247, nlb. 3, tabl. 18, il., sum. Źródła i Monografie. [T.] 236. Prace z Historii Szkolnictwa w Polsce. T. 5.

50. ŚLIŻ Małgorzata: „Uniwersytet i jego studenci”. Drugie międzynarodowe sympozjum (Praga, 12 - 15 września 2001). Studia Hist. R. 45: 2002 z. 1 s. $118-120$.

51. TRADYCJA i współczesność w edukacji dzieci i dorosłych. Pod red. Edyty Skoczylas-Krotli, Stanisława Podobińskiego, Władysława Szlufika. Częstochowa 2001 - 2002 [druk.:] 2002 Wydaw. WSP w Częstochowie ss. 658, il. Wyższa Szkoła Pedagog. w Częstochowie.

Księga poświęcona prof. Stanisławowi Gawlikowi.

Z treści: Podobiński S., Skoczylas-Krotla E., Szlufik W.: Z życia i działalności prof. dra hab. Stanisława Gawlika s. 13-16; Bugara Mariusz: Działalność oświatowa częstochowskiego oddziału RTPD [Robotnicze Towarzystwo Przyjació Dzieci] w latach 1919 - 1939 s. 31 - 42; Rędziński Kazimierz: Oświata polska pod okupacja radziecka we Lwowie w latach 1944-1945 s. 177-182; Siedlaczek[-Szwed] Aleksandra: Tradycje wychowania w Wileńskim Towarzystwie Opieki nad Dziećmi (1901-1940) s. 183-188; Szwed Robert: Organizacja i opieka nad dzieckiem w Domu Schronienia Ubogich w Krakowie (1816-1846) s. 257-263; Wiśniewska Wanda: Wspieranie idei gniazd sierocych Kazimierza Jeżewskiego [1877-1948] przez twórców kultury polskiej s. 279-287; Krzaczek Michał: Działalność studium administracji komunalnej i instytutu komunalnego (1927-1939) s. 417-426; Pękala Anna: Podręczniki szkolne do wychowania muzycznego w szkołach powszechnych II Rzeczypospolitej s. 507-517; Pękala Piotr: Polska w międzynarodowym ruchu oświatowym i pedagogicznym w latach 1918-1939 s. 519-524; Wojna Stefan: Wychowawcze walory muzykowania (na przykładzie kapeli z Szalowej) s. 541 - 552; Krzaczek Michal: Place, ubezpieczenia emerytalne i zdrowotne pracowników samorządowych w II Rzeczypospolitej - uregulowania prawne s. 571-579; Bibliografia prac jubilata. Wykaz osiagnięć w pracy naukowo-badawczej s. 641-652.

52. W DIALOGU z przeszłościa. Księga poświęcona profesorowi Janowi Hellwigowi [1931 - 2000]. Pod red. Wiesława Jamrożka, Doroty Żołądź-Strzelczyk. Poznań 2002 Wydaw. Nauk. 
UAM ss. 380 , tabl. 1, il., sum. Uniw. im. Adama Mickiewicza w Poznaniu. Psychologia i Pedagogika. Nr 114.

Z treści: Jamrożek W.: Profesor Jan Hellwig - historyk edukacji (1931 - 2000) s. 7 -10; Kabziński Krzysztof: Rola historii wychowania we współczesnym sporze o model nauk pedagogicznych s. 39-50; Bobrowska-Nowak Wanda: Inspiracje badań problematyki z zakresu historii wychowania i oświaty $w$ Polsce czerpane $z$ materiałów źródłowych i opracowań naukowych s. 51-55; Pggler Franz: Zwischen Nationalbewusstsein und Weltoffenheit: Europäische Perspektiven der pädagogischen Historiographie s. 109 -125; Żołądź-Strzelczyk D.: Dzieci niéllubne w dawnej Polsce s. 129-146; Majorek Czesław: Konserwatyzm programowy kursów metody i preparand nauczycielskich w Galicji (1805-1871) s. 175 - 186; Meissner Andrzej: Rola Lwowa w rozwoju teorii wychowania przedszkolnego w okresie autonomii galicyjskiej s. 187-202; Wróblewska Teresa: Działalność oświatowo-wychowawcza Zgromadzenia Sióstr Slużek w latach 1878-1918 s. 203-216; Stopińska-Pajak Agnieszka: Status naukowy andragogiki w Drugiej Rzeczypospolitej s. 219 - 227; Drynda Danuta: Ksztalcenie do wartości w dydaktyce Drugiej Rzeczypospolitej. Historyczne inspiracje dla współczesności s. 229-244; Wieczorek Tadeusz: Geneza ludowych szkól rolniczych w Polsce s. 245-260; Ruta Zygmunt: Warunki lokalowe i materialne seminariów nauczycielskich w Okręgu Szkolnym Lwowskim w pierwszych latach Drugiej Rzeczypospolitej s. 261 - 274; Jakubiak Krzysztof: Przyczynek do dziejów Związku Zawodowego Wychowawców Polskich Zakładów Wychowawczych (1926-1934) s. 275-281; Walczak Marian: O niektórych stratach w edukacji Polaków w latach $1939-1945$ s. 283-300; Szajek Stanisław: Pedagogika pracy Augusta Hermanna Franckego s. 303 -309; Gawlik Stanisław: Grzegorz Piramowicz -proboszcz parafii w Kurowie, Końskowoli i Międzyrzecu Podlaskim s. 311 - 321; Mokrzecki Lech: Z tradycji pozaszkolnej dzialalności oświatowej w Krakowie s. 323 -328; Jałmużna Tadeusz: Pedagogiczna i związkowa działalność Henryka Ochędalskiego s. 329-335; Koźmian Danuta: Edukacja nauczycieli szkół powszechnych i średnich w pogladach Albina Jakiela (1900-1944) s. 337-349; Woloszyn Stefan: Publicystyka pedagogiczna Janusza Korczaka okresu międzywojnia i jej zakorzenienie w rzeczywistości społecznej s. 351 - 356; Kabzińska Łucja; Józef Mirski jako propagator nowego wychowania w Polsce okresu międzywojennego s. 357 - 376.

53. WKŁAD ruchu ludowego $w$ przeobrażenie oświaty i szkolnictwa na wsi. Materiały z konferencji naukowej, która odbyła się w Kielcach w dniach 8-9 kwietnia 2002 r. Pod red. Mieczysława Adamczyka i Zdzisława Ratajka. Kielce 2002 WŚ ss. 495, il., sum. Wszechnica Świętokrzyska w Kielcach, Zarząd Gł. Lud. Tow. Nauk.-Kult. w Warszawie.

Z treści: Dunin-Wąsowicz Krzysztof: Ruch ludowy w Galicji wobec problemów oświaty na wsi s. 25-33; Wójcik Alicja: Oświata w myśli ludowej na przełomie XIX i XX wieku s. 35-47; Dobrynin Michal: Szkolnictwo polskie na Kresach Wschodnich po drugiej wojnie ŝwiatowej (Litwa, Białoruś, Ukraina) - próba analizy s. 49-60; Molenda Jan: Rola ludowców w kształtowaniu prooświatowych postaw chlopów przed 1918 r. s. 61 - 68; Giza Antoni: Szkolnictwo polskie i ruskie w Galicji Wschodniej w latach 1867 - 1914 s. 69 -76; Kolodziejczyk Arkadiusz: Ludowcy wobec problemu szkoły wyznaniowej i klerykalizacji oświaty w latach 1918-1926 s. 77-92; Krasuski Józef: Szkolnictwo i oświata w programach i działalności praktyeznej SL „Roch”w latach 1939-1945 s. 93 - 110; Matusak Piotr: Kultura w programach konspiracyjnego ruchu ludowego 1939 - 1945 s. 111 - 134; Turkowski Romuald: Ludowcy wobec problemów funkcjonowania szkolnictwa wyższego w Polsce (1945-1947/48) s. 135-151; Krasicka Zofia: Udział wojska i organizacji spolecznych w wychowaniu wojskowym i patriotycznym młodzieży na Kielecczyźnie w latach 1918-1939 s. 153-164; Stẹpka Stanisław: Społeczność wiejska wobec akcji budowy szkól tysiąclecia (1958-1966) s. 165-173; Sokól Zofia: Działalność oświatowa Marii Wyslouchowej (1858-1905) w Galicji s. 175 - 182; Dobroński Adam: Szkola Rolnicza w Krzyżewie - społeczność wiejska - ludowcy s. 183 - 191; Kłos Lilla: Seminarium Nauczycielskie w Siennicy ośrodkiem kształcenia działaczy ruchu ludowego (1866-1936) s. 193-201; Wojciechowska Jolanta: Działalność kulturalno-oświatowa Władysława Kiernika w bocheńskim Kole im. Marii Konopnickiej Towarzystwa Szkoły Ludowej w latach 1905-1914 s. 203-212; Boruta Tadeusz: Dzialalność nauczycieli na wsi podlaskiej w czasie I wojny światowej s. 213-221; Bednarzak-Libera Miroslawa: Dzjałalność oświatowo-kulturalna akademickich organizacji ludowych w II Rzeczypospolitej s. 223-243; Małolepszy Eligiusz: Rola i znaczenie prasy wiejskich organizacji młodzieżowych w popularyzacji i upowszechnianiu kultury fizycznej na wsi w okresie Il Rzeczypospolitej (zarys problematyki) s. 245-251; Indraszczyk Arkadiusz: Szkoła i teatr w myśli i działalności społecznej Adama Bienia w dwudziestoleciu międzywojennym s. 253-284; Gmitruk Janusz: Oświata dla ludu - podlaskie doświadczenia oświatowe Józefa Pietruczuka i Stefana Skoczylasa s. 285 - 295; Piotrowicz Dariusz: Czeslaw Wycech - minister oświaty $1945-1947$ s. 297-307.

54. WYŻSZE szkolnictwo kościelne w Polsce. Wizja kardynała Karola Wojtyły i jej realizacja. Red. Jędrzej Majka. Kraków 2002 Wydaw. Nauk. Papieskiej Akad. Teol. ss. 480.

Z trešci: Kubiś Adam: Papieski Wydzial Teologiczny w Krakowie 1954-1981 s. 9-164; Szostek Andrzej: Wydzial Teologiczny Katolickiego Uniwersytetu Lubelskiego s. 168-208; Bartnicki Roman: Uniwersytet Kardynała Wyszyńskiego w Warszawie. Miejsce ATK i UKSW w kościelnym szkolnictwie wyższym s. 209-256; Wojtkowski Julian: Wydzial Teologii w Olsztynie s. 257-289; Jędryszewski Marek: Wydział Teologiczny Uniwersytetu im. Adama Mickiewicza w Poznaniu s. 291-316; Bagrowicz Jerzy: Wydzial Teologiczny Uniwersytetu Mikołaja Kopernika w Toruniu s. 317-336; Sobeczko Helmut Jan: Wydzial Teologiczny Uniwersytetu Opolskiego s. 337-349; 
Myszor Wincenty: Wydział Teologiczny Uniwersytetu Slaskiego w Katowicach s. 351 - 361; Dec Ignacy: Papieski Wydział Teologiczny we Wrocławiu s. 363-389; Miazek Jan: Papieski Wydział Teologiczny w Warszawie. Sekcja - Wydzial i Sekcja w Warszawie s. 403-421; Bolewski Jacek: Bobolanum - Wydzial i Sekcja w Warszawie s. 403-443; Knapczyk Antonina Scholastyka: Międzyzakonny Wyższy Instytut Katechetyczny w Krakowie s. 423 - 443; Grzebień Ludwik: Wyższe Studiów Filozoficzno-Teologiczne Księży Jezuitów w Krakowie s. 451-470.

55. Z KART historii polskiej nauki prawa międzynarodowego. Pod red. Anny Przyborowskiej-Klimczak. Lublin 2002 Wydaw. KUL ss. 189, nlb. 2, tabl. 4.

Z treści: Karski Karol: Profesorowie Uniwersytetu Warszawskiego: Wojciech Góralczyk i Henryk de Fiumel s. 105-109; Przewoźnik Bogumila W.: Zakodowało się w mej pamięci... (Wspomnienie o profesorze Aleksandrze Bramsonie) s. 111-113; Rozwój nauki i dydaktyki prawa międzynarodowego w poszczególnych ośrodkach naukowych w Polsce: Matuszewski Wojciech: Uniwersytet Jagielloński s. 117-123; Filipek Paweł, Kuźniak Brygida: Uniwersytet Jagielloński s. 125 -131; Karski Karol: Uniwersytet Warszawski s. 133-147; Jasińska Anna, Skomerska-Muchowska Izabela: Uniwersytet Łódzki s. 149-155; Połatyńska Joanna: Uniwersytet Lódzki s. 157-158; Wierzbicki Bogdan, Perkowski Maciej, Zdanowicz Mieczysław: Uniwersytet w Białymstoku s. $159-162$; Konaszczuk Wojciech: Uniwersytet Marii Curie-Skłodowskiej w Lublinie s. 163 -165; Banach Marian, Śliwa Robert: Akademia Ekonomiczna w Krakowie s. 167-172.

56. ŻUR Piotr. Dzieje oświaty w Sosnowcu. W: Sosnowiec. 100 lat dziejów miasta. Praca zbiorowa. Pod red. Jana Walczaka. Sosnowiec 2002 s. $434-451$.

\section{Okres do 1795 roku}

57. BIAŁOBŁOCKI Adam: Początki szkolnictwa średniego we Wrocławiu. Dolny Ślask. Nr 10: 2002 s. $187-195$.

XIII-XIV w.

58. BIEGAŃSKA Anna: The learned Scots in Poland (from the mid-sixteenth century to the close of the eighteenth century). Canadian Slavonic Papers. Vol. 47: 2001 s. 1-28.

59. BIEŃKOWSKI Tadeusz: Aspekty edukacji staropolskiej (stanowe modele życia i wzory osobowe). Rozprawy z Dziejów Oświaty. T. 41: 2002 s. 7-29.

60. BRATUŃ Marek: „Ten wykwintny, wyksztalcony Europejczyk”. Zagraniczne studia i podróże edukacyjne Michała Jerzego Wandalina Mniszcha w latach 1762-1768. Opole 2002 Wydaw. UO ss. 316, tabl. 17, il., rès., Zsfg. Uniw. Opolski. Studia i Monografie. Nr 321.

61. BURDA Bogumiła: Nauczyciel, jego funkcje i zadania oraz kwalifikacje $w$ okresie wczesnonowożytnym w szkołach średnich Dolnego Ślaska. W: Historia, dydaktyka, media. Księga pamiątkowa poświęcona prof. Januszowi Rulce w czterdziestolecie pracy naukowej. Red. Barbara Tarnowska. Bydgoszcz 2002 s. $47-54$.

62. BURZYŃSKA Anna B.: Popularyzacja wiedzy o języku polskim w podręcznikach do nauczania polszczyzny na Śląsku w XVII wieku. W: O trudnym łatwo. Materiały sesji poświęconej popularyzacji nauki. Wrocław 2002 s. 87-94.

63. CHACHAJ Marian: Między Wittenberga a Rzymem. Studia polskich i litewskich biskupów, prałatów oraz kanoników na luterańskich uniwersytetach niemieckich w latach 1536-1564. W: Stosunki polsko-niemieckie w XVI-XVIII wieku. Materialy konferencji naukowej, Kielce-Szydłowiec, 19-21 października 2000. Pod red. Jacka Wijaczki. Kielce 2002 Wydaw. AŚ s. 21 - 36. Prace Instytutu Historii Akademii Świętokrzyskiej w Kielcach. Nr 31.

64. CHACHAJ M.: Studia włoskie profesorów Akademii Zamojskiej w XVI-XVIII wieku. W: Między Zachodem a Wschodem. Studia z dziejów Rzeczypospolitej w epoce nowożytnej. Pod red. Jacka Staszewskiego, Krzysztofa Mikulskiego i Jarosława Dumanowskiego. Toruń 2002 s. 175 - 187.

65. DĘBICKI Jacek: Dolnoślaskie i kłodzkie uzdrowiska studenckie w XVII - XVIII w. w ujęciu kulturowym. Wstęp do problematyki. Ślaski Kwart. Hist. Sobótka. R. 57: 2002 nr 2 s. 241-250. 
66. FLAGA Jerzy: Z problematyki nauczania prawa kanonicznego u jezuitów w XVII i XVIII wieku. Roczniki Nauk Prawnych. T. 12: 2002 z. 2 s. 37-57, sum.

67. GAWLIK Stanisław: Oświeceniowa myśl pedagogiczna w wybranych utworach Grzegorza Piramowicza. Przegl. Hist.-Oświat. R. 45: 2002 z. 1/2 s. $33-43$.

68. HOSZOWSKA Mariola: Kobiety w wybranych podręcznikach historii ojczystej drugiej połowy XVIII wieku. W: Z przeszłości Europy Środkowowschodniej. Pod red. Jadwigi Hoff. Rzeszów 2002 s. $121-145$.

69. HOSZOWSKA M.: Wizerunek kobiety w XVIII-wiecznych podręcznikach historii ojczystej. Prace Hist.-Archiw. T. 11: 2002 s. $105-118$.

70. JANECZEK Stanisław: „Świecki” charakter Komisji Edukacji Narodowej? Uwagi na marginesie lektur $z$ historii szkolnictwa. W: Divina et humana. Księga jubileuszowa w 65. rocznicę urodzin księdza profesora Henryka Misztala. Red. Antoni Dembiński, Wiesław Bar, Piotr Stanisz. Lublin 2001 s. $745-769$.

71. JEZUICKIE bursy muzyczne w Polsce i na Litwie w XVII i XVIII wieku. Kraków 2002 Wydaw. WAM; Wyższa Szkoła Filoz. - Pedagog. „Ignatianum”.

Cz. 1: Kochanowicz Jerzy: Geneza, organizacja i działalność jezuickich burs muzycznych. The foundation, structure and endeavors of the Jesuit music seminaries ss. 344, il, sum. Studia i Materiały do Dziejów Jezuitów Polskich. T. 7.

Cz. 2: Kochanowicz J.: Przepisy dotyczące jezuickich burs muzycznych. The roles governing the Jesuit music seminaries ss. 141, nlb. 1, sum. Studia i Materiały do Dziejów Jezuitów Polskich. T. 8.

Cz. 3: Grzebień Ludwik, Kochanowicz J.: Slownik jezuitów i prefektów burs muzycznych. A dictionary of Jesuit musicians and prefects in each music seminary ss. 271, nlb. 1. Studia i Materiały do Dziejów Jezuitów Polskich. T. 9.

Cz. 4: Kochanowicz J.: Słownik geograficzny jezuickich burs muzycznych. (Materiały). A decription and location each Jesuit music seminary ss. 269. Studia i Materialy do Dziejów Jezuitów Polskich. T. 10.

72. JUCKIEWICZ Paweł: Próba utworzenia uniwersytetu na Środkowym Nadodrzu w XVII wieku. Roczn. Lubuski. T. 28: 2002 cz. 1 s. $149-153$.

73. KACZMAREK Krzysztof: Studia uniwersyteckie cystersów z ziem polskich w okresie średniowiecza. Poznań 2002 Inst. Historii Uniw. im. Adama Mickiewicza ss. 177. Publikacje Instytutu Historii UAM. [T.] 42.

74. KARPIŃSKI Andrzej: Opieka społeczna nad dziećmi i młodzieżą w miastach Rzeczypospolitej w XVI-XVIII wieku. Kwart. Hist. R. 109: 2002 nr 3 s. 23-37, sum.

75. KUNERT Maria: Studenci Pedagogium Ksiażęcego w Szczecinie w XVI wieku. Warunki mieszkaniowe, obyczaje, życie towarzyskie. Przegl. Zachodniopomorski. R. 17: 2002 z. 2 s. 7-37.

76. KWAK Jan: Rola organizacji cechowych w edukacji i wychowaniu rzemieślników. Na przykładzie statutów gómośląskich i rzeszowskich z XVII - XVIII wieku. Próba podsumowania. Prace Hist.-Archiw. T. 11: 2002 s. $67-73$.

77. LITAK Stanisław: Francuski nurt w wychowaniu i szkolnictwie w Polsce w XVII i XVIII w. W: Ecclesia Posnaniensis. Opuscula Mariano Banaszak septuagenario dedicata. Red. Feliks Lenort, Konrad Lutyński. Poznań 1998 s.139-148.

78. MOKRZECKI Lech: Nauczanie historii w szkolnictwie Prus Królewskich (XVI-XVIII w.). Zarys problematyki. W: Historia, dydaktyka, media. Księga pamiątkowa poświęcona prof. Januszowi Rulce w czterdziestolecie pracy naukowej. Red. Barbara Tarnowska. Bydgoszcz 2002 s. 39-46.

79. NIEDZIELSKA Magdalena: Projekt uniwersytetu w Toruniu z 1794 roku. Zapiski Hist. T. 67: 2002 z. 1 s. $55 \cdot 70$, Zsfg.

80. NOWAK Zbigniew: Problematyka bibliologiczna w ćwiczeniach oratorskich uczniów Jana Mochingera w Gdańskim Gimnazjum Akademickim w XVII wieku. Roczn. Gdański. T. 61: 2001 z. 2 s. 23-31. 
81. PADOŁ Roman: Plan reformy Akademii Krakowskiej a „filozofia moralna” Hugona Kołłątaja. Krakowskie Studia Matopolskie. Nr 4: 2000 s. 223 -230, sum.

82. PAWLAK Marian: Studia wiejskiej luterańskiej młodzieży z Prus Królewskich w XVII - XVIII wieku. W: W służbie ksiażki. Praca zbiorowa ofiarowana doktorowi habilitowanemu Franciszkowi Mincerowi w siedemdziesiata rocznice urodzin. Pod red. Zdzisława Kropidłowskiego. [Toruń] - Bydgoszcz 2002 s. $41-58$.

83. PIPOWSKI Roman: Szkolnictwo Chełmży i okolic. Cz. 1: Od 1251 do 1772 roku. Toruń 2002 Wydaw. Adam Marszałek ss. 65. Miej. i Pow. Bibl. Publ. w Chelmży.

84. PUCHOWSKI Kazimierz: Collegium Nobilium Societatis Jesu w Warszawie wobec „dobrze oświeconej Europy". Wiek Oświecenia. T. 17: 2001 s. 129-157, rês.

Lata $1752-1773$.

85. SERWAŃSKI Maciej: Formy aktywności Kolegium Jezuickiego w Poznaniu w XVI- XVIII wieku. Mazowieckie Studia Humanist. R. 8: 2002 nr 2 s. 31 - 39.

86. WOJCIECHOWSKI Teofil: Szkolnictwo bocheńskie do 1772 roku. Studia i Materiały do Dziejów Żup Solnych. T. 22: 2002 s. $197-239$, sum.

Od XV w.

87. ŻOŁADŹ-STRZELCZYK Dorota: Dziecko w dawnej Polsce. Poznań 2002 Wydaw. Poznańskie ss. 354 , nlb. 2 , il.

XV-XVIII w.

\section{Okres $1795-1918$}

88. ADAMCZYK Kazimierz: Władysław Zamoyski jako fundator stypendiów dla mlodzieży polskiej w latach 1884 - 1914. W: W służbie ksiażki. Praca zbiorowa ofiarowana doktorowi habilitowanemu Franciszkowi Mincerowi w siedemdziesiąta rocznicę urodzin. Pod red. Zdzisława Kropidłowskiego. [Toruń]-Bydgoszcz 2002 Nasza Oficyna Wydawnicza; Akad. Bydgoska im. Kazimierza Wielkiego s. $99-108$.

89. APOZNAŃSKI Józef: Oświata w gubernii suwalskiej w okresie 1864-1900. Acta Baltico-Slavica. T. $26: 001 / 2002$ s. $273-313$, sum.

90. Bairašauskaité Tamara: Materiały do dziejów Białostockiego Instytutu Dobrze Urodzonych Panien w zbiorach Litewskiego Państwowego Archiwum Historycznego w Wilnie. Biatostocczyzna. [R. 15]: $2000 \mathrm{nr} 1$ s. $13-20$.

Działał w 1. $1841-1918$.

91. BASKE Siegfried: Reformatorskie idee Reinholda Bernharda Jachmanna z lat 1811/1812. Rozprawy z Dziejów Oświaty. T. 41: 2002 s. 65-74.

W szkole w Jankowie na Pomorzu Gdańskim.

92. BŁASZCZYK Tomasz: Wspólne zapisy regulacji prawnych Uniwersytetu Wrocławskiego i Wydziału Teologii Katolickiej w pierwszej polowie XIX wieku. Saeculum Christianum. R. 7: $2000 \mathrm{nr}$ 2 [druk.:] 2001 s. $91-100$, Zsfg.

93. BURDA Bogumiła: Zespoły kształceniowe w Sulechowie i ich związki z ziemiami polskimi oraz Łużycami na przełomie XVIII i XIX wieku. Roczn. Lubuski. T. 28: 2002 cz. 1 s. 201 - 207.

94. CIARA Stefan: Archiwa a uniwersytety w Krakowie i Lwowie w latach 1877/78-1918. Warszawa 2002 NDAP; IHUW ss. 179, sum., Zsfg. Nacz. Dyrekcja Archiwów Państ.; Inst. Hist. Uniw. Warszawskiego; Wyższa Szkoła Humanist. im. Aleksandra Gieysztora w Pultusku. 
95. CZAPSKA Małgorzata: Prywatne szkoły średnie w Królestwie Polskim w latach 1831 - 1862. Kielce 2002 Wydaw. Akad. Świętokrzyskiej ss. 424, nlb. 4, il., mapy.

96. FOLGA-JANUSZEWSKA Dorota: Uniwersyteckie poczatki Muzeum Narodowego w Warszawie. Muzealnictwo. Nr 44: 2002 s. $67-72$, sum.

XIX w.

97. GALOS Adam: Obchody rocznic uniwersyteckich. (Na trzysta lat istnienia wyższej uczelni we Wrocławiu). Ślaski Kwart. Hist. Sobótka. R. 57: 2002 nr 1 s. 1-19, Zsfg.

$\mathrm{XIX} w$.

98. GLIŃSKI Waldemar: Komisja Rządowa Wyznań Religijnych i Oświecenia Publicznego wobec wspólnot religijnych w Królestwie Polskim w latach 1815-1820. Warszawa 2002 Wydaw. Nauk. Semper ss. 211 , nlb. 1.

99. HARATYK Anna: Rozwój opieki nad dziećmi i młodzieża w Galicji doby autonomicznej. Wrocław 2002 Inst. Pedagogiki Uniw. Wrocławskiego ss. 211, nlb. 4.

100. JANICKA Iwona: Prestiż akademickiego środowiska lekarskiego w oczach społeczeństwa wileńskiego w pierwszej połowie XIX wieku. Zapiski Hist. T. 67: 2002 z. $3 / 4$ s. $89-105$, Zsfg.

101. JEMIELITY Witold: Szkoły w Łomży i Szczuczynie do I wojny światowej. W: Jakub Waga - pedagog i uczony. Pod red. Wandy Grębeckiej. Łomża 2001 ŁTN s. 127-140. Łomżyńskie Tow. Nauk. im. Wagów.

102. KALINOWSKA-WITEK Barbara: Kształcenie dziewczat w Królestwie Polskim w latach 1864 -1905. Lubelski Roczn. Pedagog. T. 22: 2002 s. 173-183.

103. KOWALSKI Krzysztof Maciej: Edukacja gimnazjalna księdza Norberta Hildebrandta w świetle zachowanych świadectw szkolnych. Z dziejów dydaktyki w Prusach Zachodnich w drugiej połowie XIX wieku. W: Pomorze - okno na świat. Studia z dziejów XIX i XX wieku. Praca zbior. pod red. Anny Paner i Michala Kosznickiego. Gdańsk 2002 s. $105-125$.

104. KRAJEWSKI Zenon: Z ziemi włoskiej do Polski. Stosunki społeczne i wychowanie w Legionach Dabrowskiego i Kniaziewicza. Tonú 2002 Wydaw. Adam Marszałek ss. 143, il.

Legiony Polskie (1797-1801) i Legia Naddunajska (1799-1802).

105. KULKA Bronisław: Deklamacja w edukacji polonistycznej w latach 1870-1918. Zarys problematyki. Przegl. Hist.-Oświat. R. 45: 2002 z. 1/2 s. $135-144$.

106. KWESTIA języka modlitwy szkolnej w memoriale księcia Aleksandra Imeretyńskiego z 23 września/5 października 1897 r. Wyd. Leszek Jaśkiewicz. W: Unifikacja za wszelka cenę. Sprawy polskie w polityce rosyjskiej na przełomie XIX i XX wieku. Studia i materiały. Pod red. Andrzeja Szwarca i Pawła Wieczorkiewicza. Warszawa 2002 243-246.

107. LOPATKIEWICZ Tadeusz: Nieznane rysunki z zapomnianej wycieczki. Uczniowie krakowskiej Szkoły Sztuk Pięknych na Podkarpaciu w 1890 roku. Roczn. Rymanowa Zdroju. T. 7: 2002 s. $37-40$, sum. s. 55 .

108. ŁUCZYŃSKA Barbara: Stosunki szkolne w Galicji na tle krystalizowania się świadomości narodowej Ukraińców. Roczn. Komisji Nauk Pedagog. T. 55: 2002 s. 15-33, sum.

109. ŁUKASIEWICZ Dariusz: Między germanizacja a modernizacją. Finansowanie szkolnictwa w Prusach Południowych w latach 1793-1806. W: Stosunki polsko-niemieckie w XVI - XVIII wieku. Materiały konferencji naukowej, Kielce-Szydłowiec, 19-21 paździemika 2000. Pod red. Jacka Wijaczki. Kielce 2002 s. $241-261$.

110. EUKASIEWICZ Dariusz: Szkolnictwo w departamencie kaliskim w świetle pruskich tabel szkolnych z 1799 roku. Roczn. Kaliski. T. 27: 2001 s. 27-46. 
11. MATUS Irena: Źródła do dziejów szkolnictwa cerkiewno-parafialnego w byłym powiecie bielskim w latach 1884 -1915. Biatostocczyzna. [R. 15]: 2000 nr 2 s. $40-44$.

Omówienie.

112. MIREK Agata: Działalność społeczna i wychowawcza pierwszych niepokalanek (1891 - 1918). Nasza Przeszlość. [T.] 97: 2002 s. 207-231, sum.

113. MOLIK Witold: Uniwersytety niemieckie w oczach polskich studentów w drugiej połowie XIX i na początku XX wieku. W: Dzieje polityczne, kultura, biografistyka. Studia z historii XIX i XX wieku ofiarowane prof. Zbigniewowi Dworeckiemu. Pod red. Lecha Trzeciakowskiego i Przemysława Matusika. Poznań 2002 s. 215-227.

114. NADPLSKI Waldemar: Poczatki turystyki w I i II gimnazjum nowosądeckim do 1914 roku. Prace Pienińskie. T. 12: 2002 s. 19-27.

Od $1891 \mathrm{r}$.

115. NIEDZIELUK Tatiana: Rzymskokatolickie organizacje dobroczynne i kulturalno-oświatowe na Syberii Zachodniej na przełomie XIX i XX w. W: Kościół katolicki na Syberii. Historia, współczesność, przyszłość. Red. nauk. Antoni Kuczyński. Wrocław 2002 Silesia s. 157-170. Uniw. Wrocławski. Inst. Historyczny. Katedra Etnologii i Antropologii Kulturowej. Ośr. Badań Wschodnich, Centrum Duchowości Klaretyńskiej, Stow. „Wspólnota Polska”. Z Prac Ośrodka Badań Wschodnich Uniwersytetu Wroclawskiego.

116. NOWIŃSKI Franciszek: Korpus Morski w Petersburgu i jego polscy absolwenci. W: Pomorze - okno na świat. Studia z dziejów XIX i XX wieku. Praca zbior. pod red. Anny Paner i Michała Kosznickiego. Gdańsk 2002 s. 145 - 171.

117. OPIEKA nad dzieckiem w Galicji. Red. Andrzej Meissner. Rzeszów 2002 Wydaw. Uniw. Rzeszowskiego ss. 220. Galicja i jej Dziedzictwo. T. 16.

Treść: Meissner A.: Teoretyczne podstawy opieki nad dzieckiem sierocym w Galicji s. 11 -28; Haratyk Anna: Udział galicyjskiego Kościoła katolickiego w pracach opiekuńczo-wychowawczych s. 29-45; Balukiewicz Malgorzata: Rozwój placówek opiekuńczo-wychowawczych dla dzieci i młodzieży we Lwowie s. 46-63; Pękowska Marzena: Opieka nad dzieckiem gluchym i niewidomym we Lwowie w XIX wieku s. 64-93; Meissner-Lozińska Justyna: Placówki opieki nad dzieckiem w Krakowie w okresie autonomii galicyjskiej s. 94 - 113; Barnas-Baran Ewa: Opieka nad dzieckiem w Krakowskim Towarzystwie Dobroczynności w latach 1816-1918 s. 114-129; Szmyd Kazimierz: Z dziejów zakonnej opieki nad dzieckiem na Podkarpaciu s. 130-151; Dolata Elżbieta: Wybrane problemy opieki nad dzieckiem w Galicji doby autonomicznej w świetle czasopisma „Szkoła”s. 152 - 164; Krzanowski Adam: Wybrane problemy opieki nad uczniami w sprawozdaniach dyrektorów gimnazjów galicyjskich s. 165-179; Horbowski Adam: Dziecko wiejskie i szkola we wspomnieniach i pamiętnikach galicyjskich s. 180 - 190; Sylwetki: Meissner A.: Natalia Cicimirska (1881-1959) s. $193-194$; Klis Teresa, Klis Andrzej: Ksiadz Bronisław Bonawentura Markiewicz (1842-1912) s. 195 - 196; Pękowska M.: Marek Makowski (1822-1894) s. 197-198; Pękowska M.: Antoni Mejbaum (1854-1916) s. 199 - 200; Krzanowski A.: Zygmunt Wyrobek (1872-1939) s. 201 - 202; Meissner A.: Barbara Żulińska (1881-1962) s. 203-206; Dolata E.: Józef Anzelm Żuliński (1841 - 1908), powstaniec 1863 r., pedagog, filantrop, działacz katolicki i spoleczny s. 207-209; Dolata E.: Tadeusz Żuliński (1839-1885), lekarz, higienista, filantrop, działacz na polu wychowania fizycznego i zdrowotnego s. 210-213; Źródła drukowane do dziejów opieki nad dzieckiem w Galicji (wybór). Sporządził A. Meissner s. 214-220.

118. POZNAŃSKI Karol: Walka caratu z polska szkołą po upadku powstania listopadowego. Przegl. Hist. - Oświat. R. 45: 2002 z. 1/2 s. 45-52.

119. RITTER Anna: Kształtowanie praw i obowiązków nauczycieli szkól elementarnych w Królestwie Polskim. Piotrkowskie Zesz. Hist. T. 2: 2000 s. 109-127, sum.

120. STRAJK dzieci wrzesińskich z perspektywy wieku. Oprac. zbior. pod red. Stanisława Sierpowskiego. Poznań-Września 2001 Bogucki Wydaw. Nauk.; Urząd Miasta i Gminy ss. 240 , i].

Trešć: Sierpowski S.: Wstęp s. 5-7; Cz. 1: Polityka germanizacyjna a społeczeństwo polskie: Sierpowski S: Stan wiedzy i ewolucja pogladów na temat strajku szkolnego we Wrześni z 1901 roku s. 11-34; Dworeckizbigniew: Charakterystyka społeczeństwa ziemi wrzesińskiej z przełomu XIX i XX wieku s. 35 - 56; Smigiel Kazimierz: Walka duchowieństwa wrzesińskiego z postepująca germanizacja s. $57-72 ; \mathrm{Cz}$. 2: Polskie i międzynarodowe echa protestów wrzesińskich: Rzepa Krzysztof: Niemcy, Prusy i zabór pruski s. 75-88; Łazuga Waldemar; Galicja i Austro-Węgry 
s. 89-104; Kijas Artur: Echa strajku w Królestwie Polskim i Rosji s.105-122; Sierpowski S.: Echa wloskie s. 123 - 140; Płygawko Danuta: Echa francuskie s. 141 - 154; Blejwas Stanisław A.: Polonia amerykańska s. 155 - 180; Cz. 3: Strajki wrzesińskie w polskiej šwiadomości narodowej: Kulczycki John J.: Strajki szkolne, nacjonalizm i świadomość narodowa s. 183 - 190; Wiśniewski Jarosław: Akcje strajkowe dzieci wrzesińskich w polskiej literaturze, publicystyce i sztuce s. 191 -208; Hendrykowska Małgorzata, Hendrykowski Marek: Obraz strajku dzieci wrzesińskich W polskim filmie s. $209-232$.

121. SZAFER Mieczysław: Edukacja po galicyjsku. Ze wspomnień mojego dziadka. [Oprac.] T. Przemysław Szafer. Teka Komisji Urbanistyki i Architektury. T. 33: 2001 [druk.:] 2002 s. 191 - 208, sum.

Tarnów, Lwów, Kraków, Monachium w L. 1865 - 1878.

122. SZUGALSKI Tomasz: Polskie nauczanie religijne w kościele św. Jana Chrzciciela i św. Jana Ewangelisty w Pile w XIX wieku. Studia Koszalińsko-Kolobrzeskie. Nr 5: 2000 s. 69-83.

123. ŚWIATTEK-OCHMANN Monika: Świadectwa kultury pedagogicznej: pedagogika żydowska w XIX wieku. Res Humana. 2002 nr 6 s. 17-20.

124. WALASEK Stefania: Polska oświata w guberni wileńskiej w latach 1864 - 1915. Kraków 2002 Impuls ss. 178, nlb. 1, il., mapa.

125. WALCZAK Eugeniusz: Szkolnictwo powszechne w powiecie kutnowskim u progu niepodległej Polski. Kutnowskie Zesz. Regionalne. T. 6: 2002 s. 365-368.

Lata $1914-1917$.

126. WINIARZ Adam: Szkolnictwo Księstwa Warszawskiego i Królestwa Polskiego (1807-1831). Lublin 2002 Wydaw. Uniw. M. Curie-Skłodowskiej ss. 586, sum.

127. WLAŹLAK Władyslaw: Organizacja szkolnictwa elementarnego w dziesiatym okręgu szkolnym obszaru piotrkowskiego (1818-1824). Częstochowskie Studia Teologiczne. [T.] 30: 2002 s. $319-334$.

128. WRÓBEL-LIPOWA Krystyna: Wartości w wychowaniu rodzinnym dzieci Stanisława Kostki Zamoyskiego [1775-1856]. W: Historia, dydaktyka, media. Księga pamiątkowa poświęcona prof. Januszowi Rulce w czterdziestolecie pracy naukowej. Red. Barbara Tarnowska. Bydgoszcz 2002 Wydaw. Akad. Bydgoskiej im. Kazimierza Wielkiego s. 69-74.

129. WRÓBLEWSKA Teresa: Problemy oświaty i nauki u schylku XVIII i w XIX wieku. Piotrkowskie Studia Pedagog. T. 9: 2001 s. 29-35.

130. WYSZCZELSKI Lech: Działalność oświatowo-wychowawcza w Wojsku Polskim do czasu odzyskania niepodległości w 1918 r. Zesz. Nauk. AON. 2000 nr 4 s. 259-276, sum.

Glównie w okresie I wojny światowej.

\section{Okres $1918-1939$}

131. ADAMCZYK Jerzy: System szkolny księdza Czeslawa Piotrowskiego jako przykład i wyzwanie dla polskich szkół katolickich. Kaliskie Studia Teol. [T.] 1: 2002 s. 185-205, Zsfg.

Realizowany w Poznaniu w 1. $1920-1939$.

132. ADAMEK Stanisław: Dziki odruch i nic więcej. (Studium pedagogiczno-historyczne o karze fizycznej). Katowice-Dąbrowa Górnicza 2002 Muzeum Miejskie „Sztygarka” ss. 158, nlb. 1, il.

W 1. $1918-1939$.

133. BAJERA-OLSZEWSKA Zofia: Działalność Komisji Opiniodawczej Ministerstwa Wyznań Religijnych i Oświecenia Publicznego w sprawie ustroju szkolnictwa muzycznego w Polsce (1928/29 r.). Rozprawy z Dziejów Oświaty. T. 41: 2002 s. 193-242. 
134. BOGUSZEWSKA Anna: Konferencje rejonowe jako forma doskonalenia nauczycieli szkół powszechnych uczacych rysunku w okresie międzywojennym. Przegl. Hist.-Oświat. R. 45: 2002 z. $3 / 4$ s. $209-212$.

135. CZUBIŃSKI Antoni: Sanacyjne próby umocnienia wpływów obozu rządowego wśród studentów Uniwersytetu Poznańskiego w latach 1926-1933. W: Dzieje polityczne, kultura, biografistyka. Studia z historii XIX i XX wieku ofiarowane prof. Zbigniewowi Dworeckiemu. Pod red. Lecha Trzeciakowskiego i Przemysława Matusika. Poznań 2002 s. 85 - 96.

136. GIERLAK Maria: Der Schüleraustausch zwischen Polen und Deutschland in den 1930er Jahren. Polnischer Pfadfinderverband (ZHP) und Hitlerjugend. Zeitschrift für Ostmitteleuropa-Forschung. Bd. 50: 2001 s. 73-94.

137. GLIMOS-NADGÓRSKA Anna: Kształcenie nauczycieli w Zagłębiu Dąbrowskim w okresie międzywojennym. W: Historia, dydaktyka, media. Księga pamiątkowa poświęcona prof. Januszowi Rulce w czterdziestolecie pracy naukowej. Red. Barbara Tarnowska. Bydgoszcz 2002 s. $75-78$.

138. KARWAT Janusz: Szkolnictwo wojsk wielkopolskich 1919-1921. W: Dzieje polityczne, kultura, biografistyka. Studia z historii XIX i XX wieku ofiarowane prof. Zbigniewowi Dworeckiemu. Pod red. Lecha Trzeciakowskiego i Przemysława Matusika. Poznań 2002 s. 39 - 52.

139. KOLASA Agnieszka: Kulturalno-oświatowa i gospodarcza działalność ludności ukraińskiej w pow. Biała Podlaska (1918-1939). Podlaski Kwart. Kult. 2002 [nr] 3/4 s. $18-25$.

140. KOMOLKA Mirosława: Działalność pozaszkolna nauczycieli Leszna w okresie międzywojennym. W: Między wielka polityka a narodowym partykularyzmem. Studia ofiarowane prof. Stanisławowi Sierpowskiemu. Pod red. Jadwigi Kiwerskiej i Bogdana Koszela. Poznań 2002 s. $151-161$.

141. KORZENIOWSKA Wiesława: Szkoły średnie Królewskiej Huty i Chorzowa dwudziestolecia międzywojennego w świetle rocznych sprawozdań ich dyrekcji. Zesz. Chorzowskie. T. 2: 1997 [druk.:] 1998 s. $308-317$.

142. KOWALCZYKÓWNA Jolanta: „Gazetka Szkolna”. Z dziejów pisemka prywatnej szkoly żeńskiej Heleny Miklaszewskiej w Łodzi. Studia i Mater. Polonist. T. 5: 2000 s. 275-284.

Lata $1924-1933$.

143. KOWALSKI Robert: Nieznane archiwalia do dziejów szkolnictwa powszechnego w Glodówce Orawskiej i Suchej Górze Orawskiej z 1939 r. Orawa. R. 12: 2000 Nr 38 s. 15-38.

W tekście dokumenty.

144. KRÓL Bronisław Władysław: Szkola jako instytucja wychowawcza w środowisku małomiasteczkowym (na tle konkretnego środowiska małomiasteczkowego - Iwieniec). Białystok 2001 BTN ss. 129, tabl. 18, il. Prace Bialostockiego Towarzystwa Naukowego. $\mathrm{Nr} 44$.

W L. $1918-1938$.

Rec.: Tomczonek Zofia, Bialostocczyzna. [R. 15]: 2000 nr 3/4 s. $154-156$.

145. ŁOJEK Mieczysław: Edukacja literacka uczniów szkół średnich w dwudziestoleciu międzywojennym. Bydgoszcz 2002 Mieczyslaw Eojek ss. 32.

146. NOWAK Krzysztof: Z dziejów szkolnych zmagań na Zaolziu. Pamiętn. Cieszyński. T. 15: 2000 s. $100-102$.

147. NOWAK Leonard: Zarzązanie wychowaniem fizycznym i sportem szkolnym w Polsce w świetle polityki państwa w latach 1918 - 1939. W: Ze studiów nad polskim dzjedzictwem w świecie. Księga dedykowana Profesorowi Edmundowi Gogolewskiemu. Pod red. Leonarda Nowaka i Marka Szczerbińskiego. Gorzów Wielkopolski 2002 s. $283-287$. 
148. OLEJNICZAK Magdalena: Religijność a wychowanie. Pedagogiczna dyskusja na łamach wybranych czasopism polskich w XX-leciu międzywojennym. Prace Nauk. UŚ w Katowicach. Nr 1978: Studia Bibliologiczne. T. 13: 2001 s. $73-82$, rez,, sum.

149. OLSZEWSKA Małgorzata: Reprezentanci społeczności żydowskiej a problemy oświaty na forum lódzkiej Rady Miejskiej w latach 1919 - 1933. Piotrkowskie Zesz. Hist. T. 3: 2001 s. 121 - 140, sum.

150. PARDYKA Anna: Polskie wady narodowe $\mathrm{i}$ ich przezwyciężanie w szkolnictwie okresu międzywojennego na przykładzie Szkoły Powszechnej w Wąwolnicy. Roczniki Humanist. T. 50: 2002 z. 2 s. $149-185$, sum.

151. PILCH Andrzej: Studenci polscy w Republice Austrii 1919-1938. Przegl. Polonijny. R. 28: 2002 z. 1 s. 5-30, sum.

152. RADZISZEWSKA Krystyna: Die deutsche Schule und Siedlungsbewegung in Łódź 1918-1939. W: Polnisch-deutsche Wechselbeziehungen im zweitem Millenium. Teil 1: Zur polnisch-deutschen Kulturkommunikation in der Geschichte - Materialien. Hrsg. von Jan Papiór; unter red. Mitarb. von Barbara Rowińska-Januszewska. Bydgoszcz 2001 s. 298-309.

153. SCHRAMM Tomasz: Tworzenie uniwersytetów. Kadry profesorskie uniwersytetów w Warszawie, Poznaniu i Wilnie u progu Drugiej Rzeczypospolitej. W: Społeczeństwo, państwo, modernizacja. Studia ofiarowane Januszowi Żarnowskiemu w siedemdziesiąta rocznicę urodzin. Pod red. Włodzimierza Mędrzeckiego. Warszawa 2002 s. $121-141$.

154. SIEMAKOWICZ Marian: Szkoły z białoruskim językiem nauczania na tle polityki władz polskich wobec ludności białoruskiej od zamachu majowego do końca II Rzeczypospolitej. Bialoruskie Zesz. Hist. Nr 17: 2002 s. $119-140$, zmest.

155. SMOLARCZYK Andrzej: Źródła do dziejów szkolnictwa podstawowego na Polesiu w okresie międzywojennym w Archiwum Państwowym Obwodu Brzeskiego. Bialostocczyzna. [R. 15]: 2000 nr 2 s. $73-79$.

156. SMOLARCZYK A.: Źródła do dziejów szkolnictwa średniego ogólnokształcącego na Polesiu w okresie międzywojennym w Archiwum Państwowym Obwodu Brzeskiego. Bialostocczyzna. [R. 16]: $2001 \mathrm{nr} 1 / 2$ s. $61-65$.

157. SOSNA Krzysztof: Chrześcijański model wychowania młodzieży w polskich publikacjach Akcji Katolickiej w latach 1930-1939. Katowice 2002 Księg. Św. Jacka ss. 165, Zsfg. Studia i Materiały Wydziały Teologicznego Uniwersytetu Ślaskiego w Katowicach. Nr 4.

158. STOLIŃSKA-POBRALSKA Nella: Instytucje opieki nad dzieckiem w międzywojennej Łodzi. Łódź 2002 Wydaw. Wyższej Szkoły Humanist.-Ekonom. ss. 309, nlb. 3, il.

159. SZCZEPAŃSKA Beata: Działalność łódzkiego samorządu miejskiego w dziedzinie oświaty powszechnej i pozaszkolnej 1919 - 1939. Łódź 2002 Wydaw. Uniw. Eódzkiego ss. 257, nlb. 2, tabl. 1, il.

160. TUROS Lucjan: Wychowanie w ujęciu Floriana Znanieckiego. Wszechnica Polska. $2002 \mathrm{nr}$ 1 s. $16-28$.

161. UMIŃSKI Wacław: Małe Seminaria prowadzone przez Księży Misjonarzy św. Wincentego a Paulo w latach $1918-1939$. Fides. [R. 7]: 2001 nr 1/2 s. $96-140$.

162. Vabiščevič Aljaksandr: Belaruskja gimnazii kul'turna-asvetnickim gramadska-palityčnym žycci Zachodnjaj Belarusi (1920 - 1930-ja gg.). Bialoruskie Zesz. Hist. Nr 18: 2002 s. 78 - 90, streszcz.

163. WAWRZEŃCZYK Stanisław: Z [Henrykiem] Dembińskim i [Czesławem] Miłoszem na Uniwersytecie Wileńskim. Arcana. Nr 45: 2002 s. 143-158.

Lata 30 - te. 
164. WIŚNIEWSKI Zbigniew: Kształcenie oficerów lączności WP w latach 1919-1921. Przegl. Hist.-Wojsk. R. 1: 2000 nr 1 s. $11-24$, sum.

165. WOJCIECHOWSKI Mieczysław: Piątki Uniwersyteckie w Toruniu - przemówienie inauguracyjne prof. dr. Zygmunta Wojciechowskiego w dniu 14 I 1938 r. W: Dzieje polityczne, kultura, biografistyka. Studia z historii XIX i XX wieku ofiarowane prof. Zbigniewowi Dworeckiemu. Pod red. Lecha Trzeciakowskiego i Przemysława Matusika. Poznań 2002 s. 265-271.

166. WYSZCZELSKI Lech: Praca oświatowo-wychowawcza w formacjach frontowych Wojska Polskiego w latach 1918-1921. Zesz. Nauk. AON. 2001 nr 3 s. 263-279, sum.

167. ŻUKOWSKA Anna Marta: Kwalifikacje zawodowe nauczycieli realizujących nauczanie rysunku w polskim szkolnictwie ogólnoksztalcącym w latach 1918 -1939. Przegl. Hist.-Oświat. R. 45: 2002 z. $3 / 4$ s. $59-75$.

\section{Okres $1939-1945$}

168. ARCHIWUM Ringelbluma. Konspiracyjne Archiwum Getta Warszawy. T. 2: Dzieci - tajne nauczanie w getcie warszawskim. Oprac. Ruta Sakowska. Warszawa 2000 Żydowski Inst. Hist. IN-B ss. XV, nlb. 2, 413, il., mapa.

169. CIEŚLA Andrzej, Kadzidłowska Katarzyna: Tajna oświata i martyrologia nauczycieli w powiecie nieszawskim w okresie okupacji hitlerowskiej 1939 - 1945. Włocławek-Toruń 2002 Woj. Ośr. Animacji Kult. ss. 107, nlb. 1, il., mapa.

170. GALLERA Rafael Christian: Antologia Szkół Podchorażych na Zachodzie w czasie II Wojny Światowej. Londyn 2002 Nakł. Fundacji Koła Szkoły Podchorążych Piechoty ss. 372, il.

171. GŁOWACKI Albin: Kadry Komitetu do Spraw Dzieci Polskich w ZSRR przy Ludowym Komisariacie Oświaty RFSRR (1943-1946). Przegl. Hist.-Oswiat. R. 45: 2002 z. 1/2 s. $17-32$.

172. GÓRAL Jan: Eksterminacja polskich nauczycieli w regionie piotrkowskim w latach okupacji hitlerowskiej (1939-1945). Roczn. Lódzki. T. 49: 2002 s. 53-72.

173. GRĘDZIK Agnieszka: Tajne nauczanie polskie na ziemiach północno-wschodnich II Rzeczypospolitej Polskiej w czasie okupacji niemieckiej 1941 - 1944. Przegl. Hist.-Oświat. R. 45: 2002 z. $3 / 4$ s. $157-192$.

174. GROCHOWINA Sylwia: Niemieckie szkolnictwo powszechne $w$ Toruniu $w$ latach 1939 - 1945. Roczn. Toruński. [T.] 29: 2002 s. $139-156$, sum., Zsfg.

175. GRZEŚ Bolesław: Projekty powojennej organizacji szkolnictwa i oświaty w programie Tajnej Organizacji Nauczycielskiej. Przegl. Hist.-Oświat. R. 45: 2002 z. 3/4 s. $77-90$.

176. JANOWSKI Marcin: Szkoły powszechne w powiecie przemyskim pod okupacja hitlerowska i sowiecka w latach 1939-1941 w świetle zasobu Archiwum Państwowego w Przemyślu. Roczn. Hist.-Archiw. T. 16: 2002 s. $39-66$, sum., Zsfg.

177. JANOWSKI M.: Tajne nauczanie w Przemyślu pod okupacja hitlerowską w świetle zasobu Archiwum Państwowego w Przemyślu. Roczn. Hist.-Archiw. T. 16: 2002 s. 67-88, sum., Zsfg.

178. KOŁODZIEJ Wincenty: Kilka uwag na temat tajnego nauczania na terenie Okręgu Szkolnego Krakowskiego podczas okupacji hitlerowskiej. Krakowskie Studia Małopolskie. Nr 6: 2002 s. 351 - 364, sum.

179. KOŁODZIEJ W.: Oświata w polskim państwie podziemnym. Krakowskie Studia Małopolskie. Nr 4: 2000 s. $263-265$. 
180. MARCINKOWSKI Tadeusz: Mały obrazek $\mathrm{z}$ historii studiów medycznych $\mathrm{w}$ Warszawie w okresie okupacji. Archiwum Hist. i Filoz. Med. T. 65: 2002 z. 1 s. 58-59.

Wspomnienia.

181. MATERNICKI Jerzy: Polska dydaktyka historii w latach 1945-2000. W: Historia, dydaktyka, media. Księga pamiątkowa poświęcona prof. Januszowi Rulce w czterdziestolecie pracy naukowej. Red. Barbara Tarnowska. Bydgoszcz 2002 s. 99-108.

182. MOLENDA Antoni, Molenda Janina: Szkolnictwo niemieckie w Chorzowie w latach 1939 - 1945. Zesz. Chorzowskie. T. 6: 2001 [druk.:] 2002 s. $198-210$, Zsfg.

183. OCALIĆ od zapomnienia. Tajna oświata w Lubelskiem 1939 - 1944. Red. Marek Jędrych. Lublin 2002 ZNP.ZO ss. 102, nlb. 15, il. Zarząd Okręgu Związku Nauczycielstwa Polskiego w Lublinie, Klub Byłych NauczycieliTajnego Nauczania.

Antologia pamiętników.

184. SAS-JAWORSKI Andrzej: Szkolnictwo i oświata polska na Zachodzie w czasie II wojny światowej. Kwart. Hist. Nauki i Techn. R. 46: 2001 nr 4 s. 188 - 204.

Ciechanowiec, 5-7 IX $2000 \mathrm{r}$.

185. ŚLESZYŃSKI Wojciech: Sowieckie domy kultury, kluby i izby-czytelnie na Białostocczyźnie w latach 1939-1941. Biatostocczyzna. [R. 16]: $2001 \mathrm{nr} 1 / 2$ s. 74-84.

186. ŚMIGIELSKA Irena: Skradzione lata. Warszawa 2001 Żydowski Inst. Hist. ss. 191, tabl. 8, il. Wspomnienia, Relacje, Dzienniki. [T.] 7.

Pamiętnik Żydówki, przedwojennej współpracowniczki pisma Janusza Korczaka „Mały Przegląd”, o pobycie w warszawskim getcie, ucieczce $\mathrm{i}$ ukrywaniu sie po aryjskiej stronie.

187. WALCZAK Marian: Edukacja dzieci polskich w Wilnie w latach 1939-1945. Przegl. Hist.-Oświat. R. 45: 2002 z. $1 / 2$ s. $5-16$.

188. WALCZAK M.: Edukacja dzieci polskich we Lwowie w latach 1939-1945. Przegl. Hist.-Oświat. R. 45: 2002 z. $3 / 4$ s. $5-26$.

189. WRONKA Ewa: „Mamo chleba... !!” Sytuacja dzieci polskich w ZSRR do połowy 1941 roku. My, Sybiracy. Nr 13: 2002 s. $10-34$.

190. WYSZCZELSKI Lech: Działalność oświatowo-wychowawcza w Polskich Siłach Zbrojnych na Zachodzie podczas II wojny światowej. Przegl. Hist.-Oświat. R. 45: 2002 z. 1/2 s. $93-107$.

\section{Okres 1945-1989}

191. APPEL Włodzimierz: Wileńskie korzenie toruńskiej filologii. W: Studia Thorunensio-Classica. Tradycje antyczne w Polsce Północnej. Red. Jerzy Axer. Warszawa 2002 s. 11-18.

192. BROWAREK Tomasz: Szkolnictwo mniejszości niemieckiej w Polsce po II wojnie światowej. Przegl. Hist.-Oświat. R. 45: 2002 z. 3/4 s. $193-208$.

193. BUDZIŁO Benedykt: Rola oświaty w życiu wsi w latach 1944 - 1989 na przykładzie gminy Gorzyce. W: Dzieje i przyszłość polskiego ruchu ludowego. T. 2: Polska Ludowa (1944/45 - 1989). Red. nauk. Waldemar Paruch, Stefan Józef Pastuszka, Romuald Turkowski. Warszawa 2002 s. 213-221.

194. BUKOWSKI Andrzej: Wkład szkolnictwa wyższego w Plocku w polepszanie stanu środowiska przyrodniczego $w$ mieście i regionie płockim. Notatki Plockie. [R. 47]: 2002 [nr] 3 s. 46-54.

Od 1959 r. 
195. CONNELLY John: Captive University. The Sovietization of East German, Czech and Polish higher education, 1945 - 1956. Chapel Hill-London 2000 The Univ. of North Carolina Press ss. XVIII, 432.

Rec.: Smaga Józef: Trzy zniewolenia. Znak. R. 54: 2002 [nr] 8 s. 155-162; Zasztowt Leszek, Rozprawy z Dziejów Oświaty. T. 41: 2002 s. 266-271.

196. DUBIELLA-POLAKOWSKA Magdalena: Życie społeczne Elblaga w latach 1945-2000. Oświata, kultura, opieka, pomoc, sport i rekreacja. Elbląg 2002 Elbląska Uczelnia Humanist.-Ekonom. ss. 580 , nlb. 1 , il.

197. FILIPKOWSKI Tadeusz: Nauczyciele w utrwalaniu dziedzictwa historycznego Warmii i Mazur. Mragowskie Studia Humanist. T. 3: 2001 s. 20-31, Zsfg.

Po 1945 r.

198. FUDALI Robert: Oświata Dolnego Śląska w okresie stalinowskim 1948/49-1955/56. Przegl. Hist.-Oświat. R. 45: 2002 z. $3 / 4$ s. $91-122$.

199. FUDALI R.: Rola społeczna nauczycieli na Dolnym Śląsku w latach 1945 - 1948. Przegl. Hist.-Oświat. R. $45: 2002$ z. $1 / 2$ s. $175-205$.

200. GŁĘBOCKI Henryk: SB wobec niezależnego ruchu studenckiego w Krakowie 1976-1980 - rekonesans archiwalny. Arcana. Nr 46/47: 2002 s. 124 - 138.

201. GRUNT Stanisław: Likwidacja Niższego Seminarium Duchownego (Collegium Marianum) w Pelplinie w świetle państwowych dokumentów archiwalnych. Studia Pelplińskie. T. 32: 2002 s. $175-227$.

Dnia 10 VIII 1961 r; w aneksie dokumenty z Archiwum Akt Nowych w Warszawie.

202. GRZECZKA Jan: Rozwój szkolnictwa podstawowego w powiecie stargardzkim w latach 1945- 1965. Stargardia. T. 2: 2002 s. $337-376$, Zsfg.

203. HOSZOWSKA Mariola: Praktyka nauczania historii w Polsce 1944 - 1956. Rzeszów 2002 Wydaw. Uniw. Rzeszowskiego ss. 219, nlb. 1.

204. HÜBNER Piotr: Neue Universitäten in Polen nach dem Zweiten Weltkrieg - ideelle und organisatorische Konzepte. Jahrbuch für Universitätsgeschichte. Bd. 4: 2001 s. 28-41.

205. HÜBNER P.: Zmiany w systemie szkolnictwa wyższego w Polsce (1960-1970). Nauka Polska - Jej Potrzeby i Rozwój. [T.] 11 (36): 2002 s. $131-165$.

206. INGLOT Mieczysław: O polonistyce wrocławskiej w latach 1957-1989. Acta Univ. Wratislaviensis. No 2408: Prace Liter. T. 41: 2002 s. 255-271.

207. IWANIUK Sławomir: Religia w szkołach $z$ językiem białoruskim w Polsce Ludowej (1944-1960). Białoruskie Zesz. Hist. Nr 17: 2002 s. $192-204$, zmest.

208. KIETLIŃSKI Marek: Białostocka opozycja młodzieżowa w latach 1982-1989. Biatostocczyzna. [R. 15]: $2000 \mathrm{nr} 2$ s. $93-112$.

209. KOSIŃSKI Krzysztof: Nastolatki '81. Świadomość młodzieży w epoce „Solidarności”. Warszawa 2002 Trio ss. 308, nlb. 1. W Krainie PRL.

210. KOSIŃSKI K.: Świadomość nastolatków w okresie „Solidarności”. Biul. IPN. Nr 12: 2002 s. $71-77$.

211. KOZERAWSKI Dariusz Stanislaw: Kształcenie kandydatów na zawodowych oficerów wojsk zmechanizowanych WP w latach 1967-1989. Wrocław 2002 WSOWLad ss. 232, il.

212. KRÓL Joanna: Szkoły średnie ogólnokształcące w województwie szczecińskim w latach 1945 - 1948 wobec potrzeb integracyjnych regionu. Przegl. Hist.-Oświat. R. 45: 2002 z. 1/2 s. 163 - 173. 
213. MAGIER Dariusz: Szkoła i rewolucja. Szkolnictwo w powiecie radzyńskim w latach 1944 - 1961. Radzyń Podlaski 2002 ss. 238.

Rec.: Bechta Mariusz, Podlaski Kwart. Kult. 2002 [nr] 3/4 s. $97-100$.

214. MEZGLEWSKI Artur: Akcja likwidacyjna niższych zakonnych seminariów duchownych w dniu 3 lipca 1952 r. W: Divina et humana. Księga jubileuszowa w 65. rocznicę urodzin księdza profesora Henryka Misztala. Red. Antoni Dembiński, Wiesław Bar, Piotr Stanisz. Lublin 2001 s. $145-157$.

215. MIELCZAREK Ferdynand: Współpraca Polskiej Partii Robotniczej z Polską Partia Socjalistyczna w zakresie ksztaltowania ideowego oblicza nauczycieli w Polsce w latach 1945-1948. Przegl. Hist. Oświat. R. 45: 2002 z. $1 / 2$ s. 207-214.

216. MIKITIUK Renata: Organizacja administracji szkolnej i szkolnictwa powszechnego na Lubelszczyźnie w latach 1944/1945. Krakowskie Studia Matopolskie. Nr 6: 2002 s. 339-349, sum.

217. MODRZYŃSKI Paweł: System szkolnictwa wyższego w Polsce. Lata 1947-1982. Rys historyczny. Krakowskie Studia Malopolskie. Nr 6: 2002 s. 521 -534, sum.

218. NOWAKOWSKA Renata: Szkolnictwo w Polsce i Niemczech 1945 - 2001. Wybrane aspekty porównawcze. Warszawa 2002 Żak ss. 178, il.

219. OBLICZE ideologiczne szkoły polskiej 1944 - 1956. Pod red. Edwarda Walewandera. Lublin 2002 Bramka ss. 426, nlb. 3, il., mapa, sum. Biblioteka Pedagogiczna Katedry Pedagogiki Porównawczej Wydziału Nauk Społecznych Katolickiego Uniwersytetu Lubelskiego. Ser. A: Studia. T. 6.

Treść: Zieliński Zygmunt: Kościół w Polsce powojennej s. 21 - 32; Nowak Marian: Pedagogika w slużbie nowej ideologii s. 33 -44; Majewski Stanisław: Szkolnictwo katolickie pod rzadami komunistycznymi w Polsce w latach 1944 - 1956 s. 45 - 80; Koźmian Danuta: Polityka oświatowa wobec szkolnictwa ogólnoksztalcącego w Polsce w latach 1944 - 1956 s. 81 - 103; Król Joanna: Ateizacja szkól średnich ogólnokształcacych w latach 1945 - 1961 na przykładzie województwa szczecińskiego s. 105-126; Grochowski Leonard: Nauka religii w szkołach państwowych Polski Ludowej. Etapy ograniczania i usuwania na tle programów laicyzacji 1944 - 1956 s. 127 -160; Turkowski Stanisław: Represje wobec katechetów archidiecezji wrocławskiej w latach 1944-1956 s. 161 - 188; Kobus Sylwia: Represje władz PRL wobec placówek opiekuńczo-wychowawczych Zgromadzenia Sióstr Urszulanek Serca Jezusa Konajacego w latach 1945- 1962 s. 189-204; Kukułowicz Teresa: Represje wobec nauczycieli w latach 1947-1956 w świetle ich wypowiedzi s. 205-210; Mauersberg Stanisław: Indoktrynacja młodzieży szkolnej. Programy, podręczniki, lektura s. 211-235; Osiński Zbigniew: Ideologizacja nauczania historii w szkołach podstawowych w latach 1944-1956 s. 237-266; Kryńska Elwira J[olanta]: Szkolne organizacje młodzieżowe w latach 1944-1956 s. 267-1956; Głowacka-Sobiech Edyta: Harcerstwo polskie w latach 1944-1956 s. 289-298; Kwiek Julian: Wychowanie religijne w harcerstwie w latach 1945-1959; Homplewicz Janusz: Autonomia i zniewolenie harcestwa wobec jego istoty i metodyki pracy s. 321 -328; Bartmiński Stanisław: Koło Ministrantów przy katedrze przemyskiej a proces ateizacji młodzieży szkolnej w latach 1944 - 1956 s. 329 - 338; Kostkiewiecz Janina: Oswiata dorosłych w latach $1944-1956 \mathrm{~s}$. 339-348; Stopikowska Małgorzata: Oblicza ideologiczne szkoły polskiej w ZSRR s. 349 - 364; Walewander E.: Polska tradycja wychowania na wychodźstwie s. 365 - 384; Chodakowska Janina: Szkoły akademickie. Grupy studenckie jako jedna $\mathrm{z}$ form upolitycznienia mlodzieży w pierwszych latach Polski Ludowej s. 385 - 388; Kamińska Janina: Potrzeba badań nad oświata polonijna we Francji 1945-1956 s. 389-396; Bartnicka Kalina: Podsumowanie: oblicze ideologiczne szkoły polskiej w latach $1945-1956$ s. $397-400$.

220. PAEYS Piotr: Próby utworzenia w Zgorzelcu w latach 1946 - 1948 gimnazjum łużyckiego. Roczn. Lubuski. T. 28: 2002 cz. 1 s. 89-97.

221. PAWELEC Ewa: Rola wydawnictw dla dzieci i młodzieży w kreowaniu ról i postaw społeczno-ideowych. Opinie recenzentów „Nowych Książek” z lat siedemdziesiątych [XX wieku]. Kieleckie Studia Bibliol. [T.] 6: 2001 s. 143 -152, sum.

222. RAWSKA Renata: „Nielegalne kolonie”. Władze PRL wobec ruchu oazowego (do roku 1980). Więź. R. 45: 2002 nr 1 s. $89-108$.

223. SALMONOWICZ Stanisław: Jak studiowałem w dobie polskiego stalinizmu. Analecta. R. 11: 2002 z. $1 / 2$ s. $313-336$, sum.

Wspomnienia o studiach prawniczych na Uniwersytecie Jagiellońskim w 1. 1950-1954. 
224. SAMUJEO Małgorzata: Kształcenie nauczycieli w Polsce - rys historyczny. Lubelski Roczn. Pedagog. T. 22: 2002 s. $189-193$.

Lata $1945-1989$.

225. SKÓRZYŃSKA Izabela: Teatry poznańskich studentów (1953-1989). Konteksty, historie, interpretacje. Poznań 2002 Wydaw. Poznańskie ss. 255, il.

226. SZUBA Ludwik: Polityka oświatowa państwa polskiego w latach 1944 - 1956. Lublin 2002 TNKUL ss. 402, nlb. 4, tabl. 18, il., sum. Tow. Nauk. KUL. Prace z Historii Szkolnictwa w Polsce. T. 6. Źródła i Monografie. [T.] 237.

227. ŚLĘCZKA Ryszard, Ryś Jan: Szkolnictwo i oświata (1945-1989). W: Limanowa. Dzieje miasta. T. 2: 1945 - 1989. Pod red. Tomasza Biedronia. Kraków 2002 Secesja s. 497-558.

228. ZABŁOCKA Maria: Romanistyka polska po II wojnie światowej. Warszawa 2002 Liber ss. 200, riass. Wydz. Prawa i Administracji Uniw. Warszawskiego.

229. ZWOLIŃSKI Piotr: Działania władz zmierzajace do laicyzacji dzieci i młodzieży szkolnej w latach 1945-1949. Lódzkie Studia Teol. R. 10: 2001 s. 177-184.

\section{Okres 1990-2002}

230. KRYŃSKI Andrzej: Niepaństwowe szkolnictwo wyższe w Polsce w latach 1990-2000. Tendencje i kierunki rozwojowe. Częstochowa 2002 Educator ss. 440, nlb. 2., il., mapa.

231. MAJ Adam: Szkolnictwo katolickie w III RP (1989-2001). Status i rozwój w okresie przemian oświatowych. Warszawa 2002 Adam ss. 300.

\section{Oświata polonijna}

232. OWCZAREK Lucjan: Polskie szkolnictwo średnie we Francji. Roczniki [Stacja Nauk. PAN w Paryżu]. T. 5: 2002 s. 75-80.

Od Szkoły Batignolles w Paryżu do Gimnazjum i Liceum im. Cypriana Norwida w Villard-de-Lens, XIX - XX w.

233. WALASEK Stefania: Problemy polskiego średniego szkolnictwa ogólnokształcącego na Łotwie w latach 1918-1940. Przegl. Hist.-Oświat. R. 45: 2002 z. 3/4 s. 43-58.

\section{DZIEJE SZKÓŁ RÓŻNYCH STOPNI}

\section{Szkoły podstawowe i zakłady wychowawcze}

234. BRZOSKOWSKI Wiesław: Historia skarszewskiej „dwójki”. (Wydano z okazji zlotego jubileuszu szkoły). Pelplin-Skarszewy 2000 Bernardinum ss. 96, tabl. 30, il.

Zespól Szkół Publicznych w Skaszewach.

235. CZWOJDRAK Dariusz: Zakład opiekuńczy dla dzieci żydowskich w Bojanowie (1926-1935). Kronika Wielkopolski. [R. 28]: $2000 \mathrm{nr} 4$ s. $19-27$.

236. DUDA Piotr: Działalność dydaktyczna i wychowawcza szkoły ludowej (powszechnej) w Uszwi w latach 1860-1939. Roczn. Tarnowski. 2001/2002 [druk.:] 2002 s. 267-276. 
237. KOGUT Mieczysław: Kronika elementarnej szkoły katolickiej w Korzeńsku. Cz. 4 [za 1. 1905 - 1928]. W: Kronika doliny Baryczy. [T.] 8. Red. Irenusz Kowalski, Mieczysław Kogut. Milicz 2000 s. $78-100$.

238. KRONIKA Publicznej szkoły nr 45 na Głównej (1945 - 1950). Kronika M. Poznania. [R. 70]: 2002 [nr] 2 s. $323-338$.

Dzielnica Poznania.

239. NADZIAKIEWICZ Elżbieta, Kinelski Paweł: Szkoła pod patronatem Anny z Dzialyńskich Potockiej. Roczn. Rymanowa Zdroju. T. 7: 2002 s. 47-49, sum. s. 56.

Dzieje szkoły w Posadzie Gómej w 1. 1895 - 2001.

240. OSIADACZ Małgorzata: Szkoła Podstawowa nr 1 w Starej Rumi we wspomnieniach jej absolwentów i nauczycieli. Rumia 2002 Szkoła Podstawowa Nr 1 im. Józefa Wybickiego ss. 108, tabl. 16 , il.

241. PACYGA Joanna, Wiecheć Aleksander: Szkola w Zawoi Centrum. Przeszłość i dzień dzisiejszy. Zawoja-Wadowice 2002 Drukarnia i Wydaw. „Grafikon” ss. 109.

XVIII - XX w.

242. PACZUSKA Zofia: Historia Szkoly Podstawowej im. Marii Konopnickiej w Nowych Groszkach. Roczn. Kałuszyński. Z. 2: 2002 s. $134-142$.

Powstala w 1919 r.

243. PAJAK Barbara: Jedynka - najstarsza szkoła Czechowic-Dziedzic. Zarys dziejów szkoły. Czechowice-Dziedzice 2002 Tow. Przyj. Czechowic-Dziedzic; Dyrekcja Szkolyy Podstawowej nr 1 ss. 103 , nlb. 1 , tabl. 6 , il.

Od XVII w.

244. [PIĘĆCZIESIATT] 50 lat Zespołu Szkół w Jelczu-Laskowicach 1952-2002. Praca zbior.; [aut.] Jerzy Byczyński [i in.]. Jelcz-Wrocław 2002 Repro ss. 64, il.

245. PNIEWSKA Krystyna: 100 lat dziejów szkolnictwa we wsi Roztropice. Kalendarz Cieszyński. [R. 19]: 2003 [druk.:] 2002 s. $77-82$.

$\mathrm{XIX}-\mathrm{XX}$ w.

246. STOKFISZ Teresa: Zarys dziejów Szkoły Podstawowej w Dąbrowicach. Kutnowskie Zesz. Regionalne. T. 6: 2002 s. $139-156$.

Lata $1885-1996$.

247. SZKOŁA Podstawowa nr 9 w Słupsku 1957 - 2002. Praca zbior. pod red. Jana Wilda. Słupsk 2002 Szkoła Podstawowa nr 9 ss. 69, tabl. 8, il.

\section{Szkoły średnie ogólnokształcące}

248. CHOJECKI Ryszard: Liceum Ogółnokształcące w Łosicach (1944-2000). Podlaski Kwart. Kult. 2001 [nr] 3/4 s. 23-34.

249. DAJNOWICZ Małgorzata: Liceum Ogólnokształcace w Suchowoli w latach 1949-1990. Bialostocczyzna. [R. 16]: $2001 \mathrm{nr} 1 / 2$ s. 116-128.

250. DRAMOWICZ Radosław: Dzieje niemieckiego gimnazjum w Międzyrzeczu (1833 - 1945). Nadwarciański Roczn. Hist.-Archiw. Nr 9: 2002 s. 89-95.

251. GIMNAZJUM i Liceum w Leżajsku 1912 - 2002. Księga jubileuszowa. Pod red. Zbigniewa Andresa. Leżajsk-Rzeszów 2002 Edytor ss. 412, tabl. 28. 
252. GŁUSZCZAK Zbigniew: Maturzyści z Paczkowa. Rocznik 1951. Opowieść o uczniach jednej klasy. Cz. 1: Lata szkolne. Paczków-Katowice 2001 Zbigniew Głuszczak; Zakład Poligraf. Karol Barwik ss. 509, il., mapa.

Toż. Cz. 2: Nasze zjazdy. Paczków-Katowice 2001 ss. 479, il.

Zawiera także wspomnienia innych absolwentów.

253. KARWOWSKA Lucyna: Królewskie Gimnazjum Ewangelickie w Toruniu (1852-1855). Konkursowy projekt budynku szkolnego w zaborze pruskim. Acta Univ. N. Copernici. Nauki Humanist.-Społ. Z. 355: Zabytkoznawstwo i Konserwatorstwo. [Nr] 33: 2002 s. 55-78.

254. KSIĘGA pamiątkowa czarniecczyków. Historia, sylwetki, wspomnienia. 80-lecie I Liceum Ogólnokształcącego im. Stefana Czarnieckiego w Chełmie. IV Zjazd Czarniecczyków 22 - 24 września 1995 r. Red. Dariusz Kostecki, Zbigniew Waldemar Okoń, Władysław [Adam] Pluta. Wyd. 2 popr. i uzup. Chełm 1995 [druk.:] 2000 Fundacja Rozwoju I Liceum Ogólnokształcącego im. Stefana Czarnieckiego ss. 285, nlb. 2, tabl. 42, il.

Z treści: Dzieje Liceum Ogólnokształcącego im. Stefana Czarnieckiego w Chełmie. Kalendarium 1915 - 1995 s. 15 - 25; Poczty sztandarowe 1920 - 1995; Prożogo Konstanty: Symbole naszej szkoły i jej pamiatki s. 28-45; Prożogo K.: Wiktor Grzegorz Ambroziewicz s. 46-51; Pluta W. A.: Stefan Mrożkiewicz (1905-1977). Szkic do portretu s. 71 - 75; Mart Krystyna: Moje wspomnienia o Marii i o Zofii Farbiszewskich s. 78 - 84; Kozlowski Waldemar Antoni: Kazimierz Pawel Janczykowski nauczyciel i tropiciel przeszłości Chełmszczyzny s. 85 -96; Pluta W. A.: Przemilczane karty historii naszej szkoły s. 141 -149; Dabrowska-Przerwa Tetmajer Alina: Z perspektywy lat 80-ciu s. 161-174; Podlewski Stanisław: Naprawdę tak bylo. Sport szkolny w latach 1944-50 s. 181-186; Aneks s. 233-285.

255. KSIĘGA pamiątkowa czarniecczyków. VII Zjazd Czarniecczyków. T. 3. Red. Marian Stopa [i in.]. Chełm 2000 Fundacja Rozwoju I Liceum Ogólnokształcącego im. Stefana Czarnieckiego; Chełmskie Tow. Regionalne ss. 369 , nlb. 3, il.

Z treści: Popek Leon: Okruchy z dziejów Szkoły Filologicznej Chełmskiej (1915 - 1917) s. 15 - 18; Sprawozdanie z dzialalności Szkoly Filologicznej Chełmskiej za rok szkolny 1917-18 s. 19-21; Ziemiński Janusz: Udział Czarniecczyków w wojnach o granice Polski Odrodzonej 1919-1920 s. 22-31; Kozlowski Waldemar A[ntoni]: Kultura fizyczna w dziejach "Czarniecczyk6w" w latach 1915-2000 s. 102 - 120; Wychowawcy i wychowankowie s. 145 -233; Kartki z przeszłości s. 237-323; Aneks s. 327-367.

256. LICEUM Ogólnokształcace Sióstr Urszulanek Unii Rzymskiej w Poznaniu. Historia szkoły urszulańskiej w Poznaniu od sprowadzenia zakonu do chwili obecnej. Praca zbior. pod kier. Przemysława Brandla. Poznań 2002 LO SS Urszulanek Uni Rzymskiej ss. 95, nlb. 1, tabl. 8, il. $\mathrm{XIX}-\mathrm{XX}$ w.

257. MACIEJCZUK Jarosław: Gimnazjum Państwowe im. J. I. Kraszewskiego w Drohiczynie n. Bugiem w okresie międzywojennym. Białostocczyzna. [R. 15]: $2000 \mathrm{nr} 3 / 4$ s. $96-103$.

258. MACIEJCZUK J: Gimnazjum Państwowe im. Tadeusza Kościuszki w Bielsku Podlaskim w okresie międzywojennym. Bialostocczyzna. [R. 16]: 2001 nr 3/4 s. $34-42$.

259. [PIERWSZE] I Liceum Ogólnokształcace im. Wojciecha Kętrzyńskiego w Giżycku w latach 1945 - 2001. Praca zbior. pod red. Tadeusza Niedźwiedzkiego i Evelyn Jelec. Wyd. 2 zm. i popr. Giżycko 2002 Wydaw. Giżyckie -Jacek Sasin ss. 197, nlb. 1, tabl. 12.

260. [PIĘĆDZIESIAT] 50 lat Liceum Ogólnokształcącego im. Stefana Batorego w Chorzowie. Praca zbior. pod red. Teresy Hantke. Chorzów 1997 III LO im. Stefana Batorego w Chorzowie ss. 163, il.

Rec.: Kurek Jacek, Zesz. Chorzowskie. T. 2: 1997 [druk.:] 1998 s. $351-354$.

261. PRYSIAŻNYJ Teodozjusz: $Z$ dziejów szkoły pijarskiej w Międzyrzeczu Koreckim na Wołyniu. Lubelski Roczn. Pedagog. T. 22: 2002 s. $185-188$, tabl. 24.

XVIII - XIX w.

262. PUSZKA Alicja: Wychowanie religijne i patriotyczne w gimnazjum państwowym w Mielcu w latach 1905-1939. Roczn. Mielecki. T. 5: 2002 s. $61-85$. 
263. RAFIŃSKI Stefan: Z dziejów gimnazjum i liceum ogólnokształcącego w Chełmnie. Wyd. 2 popr. i uzup. Bydgoszcz 2002 Bydgoskie Tow. Nauk. ss. 143, tabl. 10, il., Zsfg.

XIX-XX w.; Wyd. 1. 2001.

264. SAMODZIELNIE myśleć i wybierać. Dzieje prywatnego gimnazjum i liceum katolickiego im. św. Jacka w Katowicach 1935 - 1950. Praca zbiorowa. Pod red. Jerzego Skwary. Katowice 2002 Unia ss. 174 , il.

Z treści: Jeż Ignacy: Refleksje katechety, rektora i dyrektora szkoły w latach 1946-1960 s. 5-16; Marek Franciszek Antoni: Z perspektywy ponad 50 lat s. 17-27; Kaczmarek Witold, Trzaska Eugeniusz Jan, Jasiński Walery: Lata 1935 - 1939 s. 29-42; Kaczmarek W.: Lata 1939 - 1945 s. 43 - 48; Kaczmarek W.: Rok szkolny 1945 s. 49 - 64; Marek F. A., Horczyński Kazimierz, Maciejewski Marian, Kaczmarek W.: Rok szkolny 1945/1946 s. 65-78; Kaczmarek W., Polewka Jan: Rok szkolny 1946/1947 s. 79-96; Kaczmarek W., Maciejewski M.: Rok szkolny 1947/1948 s. 97 - 112; Skwara J.: Rok szkolny 1948/1949 s. 113 - 130; Skwara J.: Rok szkolny 1949/1950 s. 131 - 146; Klemens Jan: Lata 1950 - 1962 s. 147 - 153; Losy maturzystów z „Jacka”. Zebrał J. Skwara s. 155 - 160; Marek F. A.: Święty Jacek patron szkoły s. $163-170$.

265. STARNAWSKI Jerzy, Opalińska Bożena, Ślazykówna Magdalena: 80 rocznica patronatu Juliusza Slowackiego w I Liceum Ogólnokształcącym w Przemyślu. Roczn. Przemyski. T. 38: 2002 z. 1 s. $3-16$.

266. TRYNKOWSKI Jan: Gimnazjum. Z dziejów Gimnazjum Białostockiego (1777) 1802 - 1915. Bialystok 2002 Pol. Tow. Hist. Oddz. ss. 336, tabl. 4, il.

267. TRYNKOWSKI J.: Nauczyciele Gimnazjum Białostockiego w latach $1807-1834$. W: Studia i materiały do dziejów miasta Białegostoku. T. 5. Praca zbior. pod red. Henryka Majeckiego. Białystok 2001 s. $45-98$.

268. [TRZECIE] III Liceum Ogólnokształcące im. Władysława Broniewskiego w Ostrowcu Świętokrzyskim 1950-2002. Monografia. Zespół red. Stanisław Ziółkowski [i in.]. Ostrowiec Świętokrzyski 2002 LO im. W. Broniewskiego; Muzeum Hist.-Archeol. ss. 363, tabl. [6480], il.

269. W NASZEJ pamięci. Gimnazjum i liceum w Sandomierzu. T. 2. Zespół red. Danuta Paszkowska, Barbara Lisowska-Paterek, Aleksander Paszkowski. Sandomierz 2002 Wydaw. Diec. ss. 146, nlb. 1 , il.

Antologia wspomnień, $\mathrm{XX}$ w.

270. WAJDA Kazimierz: Maturzyści Gimnazjum Elbląskiego 1818 - 1912. Pochodzenie społeczne i wybór kierunku studiów wyższych. W: Polska i Polacy. Studia z dziejów polskiej myśli i kultury politycznej XIX i XX wieku. Księga pamiątkowa ofiarowana profesorowi Romanowi Wapińskiemu. Pod red. Mariana Mroczki. Gdańsk 2001 s. 435 - 447.

271. WALISZEWSKI Jerzy: Dar aptekarza stargardzkiego - Carla Friedricha Wilhelmy'ego na rzecz Królewskiego i Miejskiego Gimnazjum Petera Gröninga. Stargardia. T. 2: 2002 s. 433 - 436.

Z 1837 r.

W aneksie: Spis dziel podarowanych.

\section{Szkoły zawodowe}

272. HNYDA Henryk: Monografia Zespołu Szkół Drzewnych 1962-2002. Rzeszów 2002 Poligrafia Wyższego Seminarium Duchownego ss. 184, il.

ZSD im. Mikolaja Kopernika w Lesku.

273. KALIŃSKI Arkadiusz: Działalność I Cywilnej Szkoly Mechaników Lotniczych i kursów lotniczych przy Szkole Przemystowej w Bydgoszczy (1924 - 1930). Kronika Bydgoska. [T.] 23: 2002 s. $101-112$. 
274. LECHOWSKI Andrzej: Techniczna Szkola Lotnicza w Boernerowie 1945 - 1950, Zesz. Nauk AON. 2000 nr 2 s. $300-314$, sum.

Boernerowo - położone na obrzeżach Warszawy, od lat 50-tych XX w. dzielnica nosząca nazwę Bemowo.

275. LIEDKE Piotr: Polskie szkoły handlowe w Bialymstoku lat międzywojennych. Bialostocczyzna. [R. 14]: 1999 nr 4 s. $72-81$.

276. SKUBIS Helena: 50-lecie Zespołu Szkół Ekonomicznych w Częstochowie. Almanach Czestochowy. [T. 16]: 2001/2002 [druk.:] 2002 s. 225-230.

277. WALCZAK Aleksander: Morskie szkolnictwo rybackie w Polsce. Szczecin 2002 Wyższa Szkoła Morska ss. 228, nlb. 1, tabl. 24, il.

$\mathrm{XX}$ w.

278. WIECZOREK Zygmunt: Oswiata rolnicza w rejonie kępińskim i wieruszowskim oraz zarys monograficzny Zespołu Szkół Rolniczych w Słupi p. Kępnem (1910-1990). Baranów 2002 Urząd Gminy; ARP-95 Promocja Reklama ss. 226, il.

279. ZARYS monograficzny Zespołu Szkół Ekonomiczno-Gastronomicznych im. Komisji Edukacji Narodowej w 45-leciu 1957-2002. Oprac. i red. techniczna Anna Wojnowska. Wałbrzych 2002 Stow. Absolwentów Zespołu Szkół Ekonom.-Gastronomicznych im. Komisji Edukacji Nar. w Wałbrzychu ss. 80 , il.

280. ŻACZEK Tadeusz: Kształcenie pielęgniarek. Licea medyczne w województwie łódzkim 1959- 1992. Łowicz 2002 Żaczek Tadeusz ss. 400.

\section{Zakłady kształcenia nauczycieli (z wyjątkiem szkół wyższych)}

281. CHMIELEWSKI Witold: Licea pedagogiczne $w$ systemie kształcenia nauczycieli $w$ latach 1944-1956. Przegl. Hist.-Oświat. R. 45: 2002 z. 1/2 s. 145-161.

282. CHMIELEWSKI W:: Z dzialalności liceum pedagogicznego $\mathrm{w}$ Wolborzu. Piotrkowskie Studia Pedagog. T. 8: 2001 s. $129-140$.

W I. $1954-1967$.

283. DOROSZEWSKI Jerzy: Nauczyciele w seminariach nauczycielskich w Polsce w latach 1918 - 1937. Przegl. Hist. - Oświat. R. 45: 2002 z. 3/4 s. $27-41$.

284. DOROSZEWSKI J.: Seminaria nauczycielskie $w$ Polsce $w$ świetle polityki oświatowej państwa (1918-1937). Lublin 2002 Lubelskie Tow. Nauk. ss. 246, nlb. 1, il., sum., Zsfg.

285. KOWALSKI Tadeusz: Preparanda Nauczycielska w Pułtusku w latach 1918-1925. Roczn. Mazowiecki. T. 14: 2002 s. 85-98.

Dwuletnie kursy nauczania w szkolach ludowych dla zdolnych absolwentów gimnazjów.

286. SADOWSKA Joanna: Seminaria Nauczycielskie w Bialymstoku w latach 1919-1936. Bialostocczyzna. [R. 14]: 1999 nr 4 s. $63-71$.

\section{Szkoły wyższe}

\section{Akademia Ekonomiczna w Poznaniu}

287. KRASIŃSKI Zdzisław: Z 75-letnich dziejów Akademii Ekonomicznej w Poznaniu 1926 - 2001. Poznań 2002 Wydaw. AE ss. 242, il. Akad. Ekonom. w Poznaniu. 


\section{Akademia Górniczo-Hutnicza w Krakowie}

288. KLECZKOWSKI Antoni S[tanisław]: Akademia Górniczo-Hutnicza w Krakowie. Początek (1816) - założenie (1912) - otwarcie (1919). Zesz. Staszicowskie. Z. 3: 2002 s. 195-235.

289. KLECZKOWSKI A. S.: Powstanie Akademii Górniczo-Hutniczej w Krakowie w świetle dokumentów. Roczn. Bibl. Nauk. PAU i PAN w Krakowie. R. 47: 2002 s. $361-390$, tabl. 4, sum.

Lata 1913-1919; W aneksie dokumenty.

\section{Akademia Medyczna w Poznaniu}

290. CICHY Renata, Kowalski Pawel: Rys historyczny Studium Wychowania Fizycznego i Sportu Akademii Medycznej (1919-2002). W: Wychowanie fizyczne studentów i sport akademicki w badaniach naukowych. Konferencja naukowa z okazji 50-lecia Studium Wychowania Fizycznego i Sportu Akademii Rolniczej im. Augusta Cieszkowskiego w Poznaniu. Poznań 2002 s. 46-53.

\section{Akademia Obrony Narodowej}

291. SZAFRAN Czesław: Wczoraj, dziś i jutro Akademii Obrony Narodowej. Konferencja naukowa na zakończenie obchodów 10-lecia uczelni. Zesz. Nauk. AON. $2000 \mathrm{nr} 4$ s. 338-342.

Warszawa, 15 XII 2000 r.

\section{Akademia Rolnicza w Poznaniu}

292. ŁYSZCZAK Marian: Rys historyczny i perspektywy rozwoju Studium Wychowania Fizycznego i Sportu Akademii Rolniczej w Poznaniu. W: Wychowanie fizyczne studentów i sport akademicki w badaniach naukowych. Konferencja naukowa z okazji 50-lecia Studium Wychowania Fizycznego i Sportu Akademii Rolniczej im. Augusta Cieszkowskiego w Poznaniu. Poznań 2002 s. $29-38$.

\section{Akademia Wychowania Fizycznego w Gorzowie Wielkopolskim}

293. NOWAK Leonard: Instytut Wychowania Fizycznego poznańskiej Akademii Wychowania Fizycznego w Gorzowie Wlkp. 1971 - 2001. W: Studia z dziejów kultury fizycznej. Pod red. Tomasza Jurka. Gorzów Wlkp. 2002 s. 18.7-194.

\section{Akademia Wychowania Fizycznego w Poznaniu}

294. ZIÓŁKOWSKA Teresa: Z dziejów Akademii Wychowania Fizycznego w Poznaniu 1919-2001. W: Studia z dziejów kultury fizycznej. Pod red. Tomasza Jurka. Gorzów Wlkp. 2002 s. $181-186$.

\section{Katolicki Uniwersytet Lubelski}

295. KNAPIŃSKI Ryszard: Katedra Historii Sztuki Kościelnej - charakterystyka badań. Roczniki Humanist. T. 50: 2002 z. 4 s. 5-22, sum.

W Katolickim Uniwersytecie Lubelskim w 1. 1956- 2002.

296. MADEJ Krzysztof: NIK na KUL-u. Biul. IPN. Nr 7: 2002 s. 70-75.

Kontrola Najwyższej Izby Kontroli na lubelskiej uczelni w 1958 r.

\section{Metropolitalne Wyższe Seminarium Duchowne we Wrocławiu}

297. BISKUP Marian: Alumni Metropolitalnego Wyższego Seminarium Duchownego we Wroclawiu. Działalność w seminarium i w archidiecezji w latach 1947-2000. W: Unxit et misit. Księga jubileuszowa ku czci Księdza Biskupa Józefa Pazdura. Red. Ignacy Dec. Wrocław 2000 s. 159 - 174.

\section{Państwowa Wyższa Szkoła Filmowa, Telewizyjna i Teatralna w Lodzi}

298. NAWROT Grzegorz: Państwowa Wyższa Szkoła Filmowa, Telewizyjna i Teatralna w Łodzi i jej archiwum. Biul. IPN. Nr 4: 2002 s. 51-57. 


\section{Państwowa Wyższa Szkoła Teatralna w Warszawie}

299. RASZEWSKA Magdalena: Wiedza o teatrze w warszawskiej PWST. Próba rekapitulacji. Pamiętn. Teatr. R. 51: 2002 z. $1 / 2$ s. $238-323$.

Od r. 1932.

Uzup.: Nauka o teatrze (1972-1973). Zebrała i oprac. Marzena Kuras. Tamzie s. 324-337.

\section{Papieski Wydzial Teologiczny we Wrocławiu}

300. MŁOTEK Antoni: Piękna dama Teologia. 300 lat Wydziału Teologicznego we Wrocławiu 1702-2002. Wrocław 2002 Papieski Wydz. Teol. ss. 106, nlb. 4.

301. [TRZYSTA] 300 lat Wydziału Teologicznego we Wrocławiu. Zarys historii i pracownicy naukowi PWT we Wrocławiu. Pod red. Ignacego Deca. Wrocław 2002 Papieski Wydz. Teol. ss. 248, il.

Z treści: Swastek Józef: Korzenie uniwersyteckiej teologii na Slasku do 1702 roku s. 15-25; Lec Zdzisław:Założenie Akademii Leopoldyńskiej we Wrocławiu w 1702 r. s. 27-32; Kogut Mieczysław: Działalność Akademii Leopoldyńskiej (1702-1811) s. 33-41; Kiełbasa Antoni: Teologia na Uniwersytecie Wroctawskim w latach 1811 - 1870 s. 43-47; Pater Mieczysław: Wydział Teologiczny na Uniwersytecie Wroclawskim $(1870-1918) \mathrm{s}$. 49-58; Mandziuk Józef: Nauczanie teologii katolickiej na Uniwersytecie Wrocławskim w okresie międzywojennym s. 59-63; Pater J6zef: Starania o reaktywowanie Wydziału Teologicznego na Uniwersytecie Wroclawskim po drugiej wojnie światowej s. 65-76; Dec I.: Papieski Wydzial Teologiczny we Wrocławiu s. 77-84; Biskup Marian: Ksztalcenie teologiczne w Wyższym Seminarium Duchownym we Wrocławiu w latach 1947-1968 s. 85-92; Biogramy pracowników naukowych Papieskiego Wydziału Teologicznego we Wroclawiu s. 121-182.

\section{Politechnika Gdańska}

302. MATERIALY sesji naukowej z okazji 50-lecia Wydziału Elektroniki, Telekomunikacji i Informatyki. Gdańsk 2002 Wydaw. Politech. Gdańskiej ss. 186, nlb. 1, il., sum., streszcz.

303. WEISS Katarzyna: Polacy na Politechnice Gdańskiej w okresie międzywojennym. W: Polacy i sasiedzi -dystanse i przenikanie kultur. Zbiór studiów. Cz. 3. Pod red. Romana Wapińskiego. Ostaszewo Gd[ańskie] 2002 s. 176-199.

\section{Politechnika Łódzka}

304. CYWIŃSKA Urszula: Inżynieria chemiczna i procesowa w Łodzi. Krótki zarys historii. Łódź 2002 Wydz. Inżynierii Procesowej i Ochrony Środowiska Politech. Łódzkiej. Wydaw. ss. 148, il.

Księga pamiątkowa poświęcona Mieczysławowi Serwińskiemu (1918-1999) oraz Wydziałowi Inżynierii Procesowej i Ochrony Srodowiska Politechniki Łódzkiej.

\section{Polski Wydział Lekarski w Edynburgu}

305. LISOWSKI Witold: Powstanie i dzialalność Polskiego Wydziału Lekarskiego w Edynburgu (1941-1949). Przegl. Hist.-Wojsk. R. 1: 2000 nr 2 s. 5-28, sum.

\section{Prymasowskie Wyższe Seminarium Duchowne w Gnieźnie}

306. KSIĘGA Jubileuszowa Prymasowskiego Wyższego Seminarium Duchownego w Gnieźnie 1602 - 2002. Red. Paweł Podeszwa, Wojciech Polak. Gniezno 2002 Prymasowskie Wyższe Seminarium Duchowne ss. 400 , il.

Z treści: Aleksandrowicz Marian: Początki Seminarium Duchownego w Gnieźnie (1602-1718) s. 17-23; Rospond Stanisław: Formacja alumnów w polskich seminariach diecezjalnych pod zarzadem Zgromadzenia Księży Misjonarzy (1675-1835) s. 25-41; Pest Czesław: Losy Arcybiskupiego Seminarium Duchownego w Gnieźnie w czasie niewoli narodowej i w niepodległej ojczyźnie (do 1953) s. 43-76; Śmigiel Kazimierz: Geneza rozdziału i scalenia Seminarium Duchownego w Gnié́nie (1835, 1953) s. $77-86$; Polak W.: Akademicki charakter studiów w Prymasowskim Wyższym Seminarium Duchownym w Gnieźnie s. 87-93; Wojtus Bogdan: Budowa nowego gmachu Prymasowskiego Wyższego Seminarium Duchownego w Gnieźnie s. 95-100; Lisiecki Maciej, Polak W.: Kościól seminaryjny pod wezwaniem św.Jerzego na Wzgórzu Lecha s. 103 - 108; Rył Jadwiga: Biblioteka Seminarium Duchownego w Gnieźnie s. 109-142; Mikołajczyk Gabriela, Gałęzewska Krystyna, Maciejewski Leonard: Opieka lekarska nad alumnami, profesorami i siostrami zakonnymi Prymasowskiego Wyższego Seminarium Duchownego w Gnieźnie od XVII do XXI wieku s. 143-148; Sylwetki s. 157-246; Wspomnienia s. 249-342. 


\section{Seminarium Duchowne w Plocku}

307. GRZYBOWSKI Michał Marian: Osiemnastowieczny księgozbiór biblioteki seminarium duchownego w Płocku. W: W służbie ksiażki. Praca zbiorowa ofiarowana doktorowi habilitowanemu Franciszkowi Mincerowi w siedemdziesiąta rocznicę urodzin. Pod red. Zdzisława Kropidłowskiego. [Toruń]-Bydgoszcz 2002 s. $59-84$.

\section{Seminarium Duchowne we Włocławku}

308. RULKA Kazimierz: Księgozbiory profesorów ze Zgromadzenia Księży Misjonarzy w bibliotece seminarium włocławskiego. Studia Wtoctawskie. T. 5: 2002 s. 412-438.

M.in. Jana Średnickiego (1794-1840), Józefa Pawlickiego (1802-1868), Franciszka Płoszczyńskiego (1800 - 1873).

309. RULKA K.: Księgozbiór Adama Chodyńskiego [1832-1902] na podstawie materialów zachowanych w Bibliotece Seminarium Duchownego we Włocławku. Archiwa, Bibl. i Muzea Kośc. T. 77: 2002 s. $269-286$, Zsfg.

\section{Szkoła Główna Gospodarstwa Wiejskiego}

310. PIERWSI powojenni. Wspomnienia pierwszych powojennych studentów Wydziału Rolniczego SGGW. Zespół red. Andrzej Brudzyński [i in.]. Warszawa 2002 Fundacja „Rozwój SGGW” ss. 275, nlb. 1, tabl. 32, il. Zeszyty Historyczne Stowarzyszenia Wychowanków Szkoły Głównej Gospodarstwa Wiejskiego w Warszawie. Z. 3.

\section{Uniwersytet Wrocławski}

311. WŁODARCZYK Jaroslaw: Instrumenty Obserwatorium Astronomicznego Uniwersytetu Wroclawskiego: XVIII-XX wiek. Kwart. Hist. Nauki i Techn. R. 47: 2002 nr 3 s. 75-92, sum.

\section{Uniwersytet Dorpacki}

312. BEDNARSKI Zenobiusz Michal: Polacy na Wydziale Lekarskim Uniwersytetu Dorpackiego w latach 1802 - 1889. Olsztyn 2002 Tow. Nauk. OBN ss. 174, nlb. 2, tabl. 8, il. Rozprawy i Materiały Ośrodka Badań Naukowych im. Wojciecha Kętrzyńskiego w Olsztynie. Nr 207.

\section{Uniwersytet im. Adama Mickiewicza}

313. ALMA mater posnaniensis - w 80. rocznicę utworzenia Uniwersytetu w Poznaniu. Pod red. Przemysława Hausera, Tomasza Jasińskiego, Jerzego Topolskiego. Poznań 1999 Wydaw. Nauk. UAM ss. 304 .

\section{Uniwersytet Jagielloński}

314. CZERKAWSKI Jan: Aristotelianism at Cracow University in the sixteenth century. Acta Mediaevalia. T. 15: 2002 s. $215-232$, streszcz.

315. DYBIEC Julian: Uniwersytet Jagielloński wobec stalinizmu 1945-1956. Prace Komisji Historii Nauki. T. 3: 2001 s. 5-20.

Uzup.: Dyskusja nad referatem ... Tamże s. 20-33.

316. KOHLER Piotr: Historia Zielnika Instytutu Botaniki Uniwersytetu Jagiellońskiego (KRA) w latach 1910-2000. Kwart. Hist. Nauki i Techn. R. 46: 2001 nr 4 s. 77-104, sum.

317. KUBIŚ Adam: Wydział Teologiczny Uniwersytetu Jagiellońskiego. Ostatni etap. Polonia Sacra. R. 6: $2002 \mathrm{nr} 10$ s. $229-242$, Zsfg.

Lata $1939-1965$.

318. MARKOWSKI Mieczysław: Die Grundzüge der Krakauer Artistenfakultät in späten Mittelalter. Acta Mediaevalia. T. 15: 2002 s. $117-130$, streszcz. 
319. MARKOWSKI M.: Jagiellońska przemiana struktury Uniwersytetu Krakowskiego w 1400 roku. Studia Warmińskie. T. 39: 2002 s. 55-70, Zsfg.

320. MARKOWSKI M.: Od Kazimierzowskiej do Jagiellońskiej fundacji Uniwersytetu w Krakowie. Acta Mediaevalia. T. 15: 2002 s. 13-43, Zsfg.

321. MYCIELSKI Przemysław: Cieszyńscy absolwenci Uniwersytetu Jagiellońskiego w średniowieczu i dobie wczesnonowożytnej. Pamiętn. Cieszyniski. T. 17: 2002 s. 31-35.

XV-XVI w.

322. NATOŃSKI Bronisław: Jezuici a Uniwersytet Krakowski w XVI wieku. Red. nauk. Ludwik Grzebień. Kraków 2002 Wyższa Szkoła Filoz.-Pedagog. „Ignatianum”; Wydaw. WAM ss. 142, nlb. 1, sum., rés. Klasycy Jezuickiej Historiografii. T. 1.

323. SOKOŁOWSKA-PITUCHOWA Janina: 400 lat katedry anatomii w Krakowie (1602 - 2002). Kraków 2002 Wydaw. UJ ss. 242, il.

324. SONDEL Janusz: Dzieje Katedry Prawa Rzymskiego Uniwersytetu Jagiellońskiego w czasach I Rzeczypospolitej. W: Dziedzictwo prawne XX wieku. Księga pamiatkowa z okazji 150-lecia Towarzystwa Biblioteki Słuchaczów Prawa Uniwersytetu Jagiellońskiego. Aut. Kazimierz Baran [i in.]; kom. red. Andrzej Zoll, Jerzy Stelmach, Jan Halberda. Kraków 2002 s. 169-216.

325. SONDEL J.: Prawo rzymskie na Uniwersytecie Jagiellońskim od reformy [Hugo] Kołłątaja do 1945 roku. W: Studia z historii ustroju i prawa. Księga dedykowana Profesorowi Jerzemu Walachowiczowi. Pod red. Henryka Olszewskiego. Poznań 2002 s. 347-381.

326. STERNALSKI Marek: Poczatki psychiatrii uniwersyteckiej w Krakowie. Alma Mater. Nr 46: 2002 s. $26-28$.

Lata $1862-1912$.

327. ŚREDNIAWA Bronisław: Historia filozofii przyrody i fizyki w Uniwersytecie Jagiellońskim. Warszawa 2001 Retro-Art ss. 285. Komitet Historii Nauki i Techniki. PAN. Rozprawy z Dziejów Nauki i Techniki. T. 12.

Rec.: Strzalkowski Adam, Kwart. Hist. Nauki i Techn. R. 47: 2002 nr 1 s. 246-251.

328. TERLECKI Ryszard: Profesorowie UJ w aktach UB i SB. Kraków 2002 Wydaw. Liter. ss. 221 , nlb. 3.

Rec.: Salmonowicz Stanisław: Profesorowie Uniwersytetu Jagiellońskiego jako przedmiot inwigilacji organów UB i SB. Czasy Nowożtne. T. 13: 2002 s. 179-194.

329. WOJTCZAK Hanna: Das Wissenschaftliche Wirken Benedikt Hesses an der Krakauer Universität in der ersten Hälfte des 15. Jahrhunderts unter besonderer Berücksichtigung der Artistenfakultät. Acta Mediaevalia. T. 15: 2002 s. $303-322$, streszcz.

330. ZAREBBINA Maria: Profesor Stanisław Urbańczyk i tajne nauczanie w Uniwersytecie Jagiellońskim. Jęz. Pol. R. 82: 2002 z. 1 s. $51-53$.

331. ZIEJKA Franciszek: Związki Podhala z Uniwersytetem Jagiellońskim. Almanach Nowotarski. Nr 6: 2002 s. $43-49$.

Od XVI w.

332. ZŁOTA Księga Wydziału Chemii. T. 1. Pod red. Elżbiety Szczepaniec-Cięciak. Kraków 2000 Wydaw. UJ ss. 446 , il.

Rec.: Zamecki Stefan, Kwart. Hist. Nauki i Techn. R. 47: 2002 nг 2 s. 143-157.

\section{Uniwersytet Jana Kazimierza}

333. WOŁCZAŃSKI Józef: Wydział Teologiczny Uniwersytetu Jana Kazimierza we Lwowie 1918 - 1939. Kraków 2002 Wydaw. Bł. Jakuba Strzemię Archidiecezji Lwowskiej Ob. Łac. ss. 674, nlb. 
3, tabl. 72, il., sum. Biblioteka Historyczna Archiwum Metropolii Lwowskiej Obrządku Lacińskiego w Krakowie. Ser. B: Studia. T. 5.

\section{Uniwersytet Kardynała Stefana Wyszyńskiego}

334. URBAŃSKI Stanisław: 185. rocznica Wydziału Teologicznego Uniwersytetu Kardynała Stefana Wyszyńskiego(1816-2001). Ateneum Kapl. T. 138: 2002 z. 1 s. 200-211.

335. URBAŃSKI S.: 185. rocznica Wydziału Teologicznego Uniwersytetu Kardynała Stefana Wyszyńskiego (1816-2001). Studia Theologica. Varsoviensia. R. 40: 2002 [nr] 1 s. 13-28.

\section{Uniwersytet Kólewiecki}

336. GRABOWSKI Jan: Metereologia i agrometereologia na Uniwersytecie Królewieckim. Biul. Nauk. Uniw. Warmińsko-Mazurski. Nr 15: 2002 s. 241-247.

\section{Uniwersytet Mikołaja Kopernika}

337. WRÓBLEWSKI Witold: Katedra Filologii Klasycznej Uniwersytetu Mikołaja Kopernika w latach 1945 - 1995. W: Studia Thorunensio-Classica. Tradycje antyczne w Polsce Północnej. Red. Jerzy Axer. Warszawa 2002 s. 19-24.

\section{Uniwersytet Warmińsko-Mazurski w Olsztynie}

338. WOJTKOWSKI Julian: Wydział Teologii Uniwersytetu Warmińsko-Mazurskiego w Olsztynie. Studia Warmińskie. T. 39: 2002 s. $441-470$.

\section{Uniwersytet Warszawski}

339. JAŚKIEWICZ Leszek: Uniwersytet Warszawski w dokumentach carskiego Departamentu Policji z przełomu XIX i XX w. W: Unifikacja za wszelką cenę. Sprawy polskie w polityce rosyjskiej na przełomie XIX i XX wieku. Studia i materiały. Pod red. Andrzeja Szwarca i Pawła Wieczorkiewicza. Warszawa 2002 s. $153-158$.

340. SCHILLER Joanna: Powstanie Cesarskiego Uniwersytetu Warszawskiego w świetle badań archiwalnych. Rozprawy z Dziejów Oświaty. T. 41: 2002 s. 93-127.

$1869 \mathrm{r}$.

341. SOŁTYSIAK Arkadiusz, Jaskulski Piotr: Antropologia na Uniwersytecie Warszawskim. Warszawa 2000 Inst. Archeol. Uniw. Warszawskiego ss. 116, nlb. 2.

$\mathrm{XX}$ w.

\section{Uniwersytet Wileński}

342. Kivilšienè Rasa, Klimka Libertas: Fizyka pod wpywem Komisji Edukacji Narodowej na dawnym Uniwersytecie Wileńskim. Kwart. Hist. Nauki i Techn. R. 46: 2001 nr 4 s. 61-76, sum.

Lata $1773-1832$.

\section{Uniwersytet Wrocławski}

343. ABSOLWENCI Uniwersytetu Wroclawskiego. T. 1: 1946 - 1989. Oprac. Urszula Czwojdrak [i in.]; pod red. Teresy Suleji. Wrocław 2002 Wydaw. Uniw. Wrocławskiego ss. 486.

Listy absolwentów $z$ kolejnych roczników.

344. JUREK Piotr: $Z$ dziejów Wydziału Prawa Uniwersytetu Wrocławskiego - kilka refleksji. Acta Univ. Wratislaviensis. No 2342: Przegl. Prawa i Administracji. T. 50: 2002 s. 15-29.

XVIII - XX w.

345. KULAK Teresa, Pater Mieczysław, Wrzesiński Wojciech: Historia Uniwersytetu Wrocławskiego 1702 - 2002. Wroclaw 2002 Wydaw. Uniw. Wrocławskiego ss. 405, nlb. 3, il., mapa, sum. Acta Universitatis Wratislaviensis.[No] 2402. 
346. KUNICKI Wojciech: Modernisierung als Politisierung? Modernisierung versus Politisierung? Germanistische Forschung und Lehre an der Universit(t in Breslau 1877 - 1944. W: Germanistik 2000 Wroclaw-Breslau. Hrsg. von Norbert Honsza. Wrocław 2001 s. 37-68.

347. KUNICKI W.: Polska germanistyka we Wrocławiu. Dolny Śląsk. Nr 10: 2002 s. $125-133$. Lata $1945-2002$.

348. RUCHNIEWICZ Krzysztof: Lwowskie tradycje Uniwersytetu Wrocławskiego. W: Wrocław-Lwów, Lwów-Wroclaw. Historia i współczesność. Red. Danuta Nespiak, Małgorzata Orzel. Wrocław 2002 s. $115-123$.

349. TRZYSTULECIE Uniwersytetu we Wrocławiu. Ślaski Kwart. Hist. Sobótka. R. 47: $2002 \mathrm{nr}$ 3 s. $295-429$, nlb. 2, Zsfg.

Treść: Galos Adam: Przedmowa s. 295-296; Dziurla Henryk: Leopoldina w historycznej przestrzeni Wroclawia s. 297-314; Blaszczyk Tomasz: Stan i reforma oświaty na Śląsku w czasach pruskich do 1811 r. s. $315-330$; Lec Zdzislaw, Młotek Antoni: Teologia katolicka na Uniwersytecie Wrocławskim w XIX w. s. 331 -344; Ergetowski Ryszard: Naukowa i dydaktyczna działalność Jacoba Caro s. 345-356; Pater Mieczysław: Przesłanie Uniwersytetu Wroclawskiego do Uniwersytetu Jagiellońskiego w 500 rocznicę jego odnowienia s. 357-366; Kisiel Robert: Korpus [Adolfa Ludwiga Wilhelma von] L(tzowa - wojsko z tradycji wroclawskiej Almae Matris s. 367 - 382; Jonca Karol: Idee polityczne i spoleczne profesora prawa Eugena Rosenstocka-Huessego s. 383-392; Dec Ignacy: Studia teologiczne we Wrocławiu po II wojnie światowej s. 393-405; Suleja Teresa: Próby kształtowania „nowego czlowieka" w czasach stalinowskich (na przykładzie Uniwersytetu Wrocławskiego 1949-1953) s. 407-420; Tyszkiewicz Jakub: Polskie badania nad dziejami wrocławskiej Almae Matris po II wojnie światowej s. 421 - 429.

\section{Wojskowa Akademia Techniczna}

350. KAZIMIERSKI Zygmunt: Grupa Organizacyjno-Przygotowawcza Wojskowej Akademii Technicznej. Przegl. Hist.-Wojsk. R. 1: 2000 nr 2 s. 44-54, sum.

Powstała w 1950 r.

\section{Wyższa Szkoła Oficerska Wojsk Obrony Przeciwlotniczej}

351. ORZECHOWSKI Jerzy: Rys historyczny Wyższej Szkoły Oficerskiej Wojsk Obrony Przeciwlotniczej i Centrum Szkolenia Obrony Przeciwlotniczej w Koszalinie (1948-2001). W: Problemy militame na Pomorzu w latach1914-1989. Red. nauk. Adolf Stachula. Słupsk 2002 s. $167-196$.

\section{Wyższe Seminarium Duchowne Towarzystwa Salezjańskiego w Lądzie}

352. KSIĘGA jubileuszowa. Red. Marek T. Chmielewski. Ląd 2002 Wyższe Seminarium Duchowne Tow. Salezjańskiego ss. 356, il., riass., sum., Zsfg.

50 lat Wyższego Seminarium Duchownego Towarzystwa Salezjańskiego w Lądzie nad Warta $(1952-2002)$.

\section{Wyższe Seminarium Duchowne w Pelplinie}

353. PISZCZ Edmund: Z dziejów Seminarium Duchownego w Pelplinie. Wykład okolicznościowy. Studia Pelplińskie. T. 32: 2002 s. 319-325.

Z okazji 350-lecia WSD w Pelplinie.

354. WITTA Rafał: Wyższe Seminarium Duchowne w Pelplinie w latach 1976-1992. Przyczynek do historii. Studia Pelplińskie. T. 33 [wyd. specjalne]: 2002 s. 625-633.

\section{BIOGRAFIE}

\section{Zbiory życiorysów}

355. BIOGRAFIE nauczycieli zasłużonych dla oświaty i środowiska regionu puławskiego. T. 1. Oprac. red. Stanisław Jednacz, Danuta Kaliszczuk. Puławy 2002 Tow. Przyj. Muzeum Oświatowego ss. 147 , nlb. 2 , il.

$\mathrm{XIX}-\mathrm{XX}$ w. 
356. DUDA Jerzy, Andrzejewska-Wasilenko Alicja: Doskonalenie nauczycieli na Śląsku Opolskim 1948-2001. Słownik biograficzny. Opole 2002 WOM ss. 97, il. Woj. Ośr. Metodyczny.

357. DUDA J., Szelka Anna, Dzionek Franciszek: Słownik biograficzny nauczycieli na Śląsku Opolskim. Cz. 6. Opole 2002 Zarząd Okręgu Zwiazku Nauczycielstwa Polskiego ss. 169, il.

$\mathrm{XX}$ w.

Cz. 1 pt.: Slownik biograficzny nauczycieli Sląska Opolskiego. Opole 1995.

358. HISTORIA wychowania. Słownik biograficzny. Pod red. Andrzeja Gąsiorowskiego. Wyd. 2 uzup. Olsztyn 2002 Wydaw. Uniw. Warmińsko-Mazurskiego ss. XVIII, nlb. 2, 180, il.

Wyd. 1. 1994.

359. KSIEGA wspomnień. O zmarłych pracownikach powojennej polonistyki wrocławskiej. Pod red. Mariana Ursela. Wrocław 2002 Wydaw. Uniw. Wrocławskiego ss. 328, il. Acta Universitatis Wratislaviensis. No 2374.

Treśc: Ursel M.: Slowo wstępne s. 5- 6; Klimowicz Mieczyslaw: Tadeusz Mikulski - uczony i humanista czasów zamętu (17.01.1909-26.08.1958) s. 7-50; Piasecki Zdzislaw: O Stanislawie Kolbuszewskim garść wspomnień (22.06.1901-7.01.1965) s. 51 -76; Żarski Waldemar: Halina Waszkis (16.12.1931-23.10.1973) s. 77-80; Soliński Wojciech: W poszukiwaniu czasu niknacego w cieniu wulkanu. O Aleksandrze Berezie (12.01.1933-25.08.1975) S. 81 -91; Inglot Mieczysław: Wspomnienie o Jerzym. Jerzy Cieślikowski (2.11.1916-9.11.1977) s. 92-113; Nowińska Alina: Gabriela Frydrychowicz - niezwykły czlowiek, bibliotekarz, bibliograf (2.03.1921 - 22.04.1980) s. 114 - 126; Soliński Wojciech: Gdzie sa chlopcy z tamtych lat... O Jurandzie Banachu (12.06.1950-22.12.1980) s. 127 - 131; Peisert Maria: Stanisław Bąk (28.11.1900-10.06.1981) s. 132-145; Hernas Czesław: Roman Sobol (4.07.1926-23.04.1982) s. 146 - 158; Łobodzińska Romana: Stanisław Rospond (19.12.1906-16.10.1982) s. 159- 190; Slękowa Ludwika: Masia. O Marii Eustachiewicz (29.09.1930 - 14.05.1990) s. 191 - 199; Inglot M.: Moje spotkanie z Władyslawem Leopoldem Floryanem (16.10.1907-2.03.1991) s. 200-219; Kolbuszewski Jacek: Bernard Woodrow Januszewski (2.07.1919-9.05.1994) s. 220-231; Pyszny Joanna: Piękno filmu, piękno życia. O Piotrze Lisie (10.06.1952-13.02.1995) s. 232-244; Pięczka Bogdan: Czlowiek pełen właściwości. O Janie Trzynadlowskim (29.12.1912 - 18.05.1995) s. 245 - 274; Woronczak Jerzy; Maria Michalak (6.04.1927 - 29.12.1996) s. 275 - 278; Żabska Boguslawa: Wspomnienia o Teresie Bulicz[-Tornikidis] (26.09.1936-24.07.1997) s. 279-284; Zawada Andrzej: O Lotharze Herbście (27.07.1940-27.04.2000) s. 285-299; Skawiński Jacek: Pamięci Janusza Anusiewicza $(19.05 .1946-26.12 .2000)$ s. $300-310$; Nieckula Franciszek; Wspominki o Bogdanie Sicińskim (16.11.1931-22.01.2001) s. $311-320$.

Po biogramach bibliografie prac.

360. LEKSYKON ludzi ZSP [Zrzeszenia Studentów Polskich]. T. 1. Oprac. zespół red. w składzie Zenon Skuza, Włodzimierz Ulicki. Warszawa 2002 Elipsa ss. 335, nlb. 1, il.

XX $w$.

361. LOSY pedagogów polskich na Wschodzie. Wstępem i przypisami opatrzył oraz podał do dr. Edward Walewander. Warszawa 2002 Stow. Współpracy Polska-Wschód ss. 166, nlb. 3, tabl. 17, il. Bibl. Pedagog. Katedry Pedagogiki Porównawczej Wydz. Nauk Społ. KUL. Ser. B. Materiały i Dokumenty. T. 5.

Treść: Walewander E.: Wstęp s. 7-10; Mamulska Anna: Z doświadczeń nauczycielskich na rumuńskiej Bukowinie s. 11 -59; Studzińska-Hubert Slawa: Moje gimnazjum w Eucku. Gimnazjum Polskiej Macierzy Szkolnej im. Tadeusza Kościuszki s. 61-132; Grochowski Andrzej: Siedemdziesiat lat harcerstwa polskiego w Chinach s. 133 - 140; Grochowski A.: Tobrukczyk z Harbina. Wspomnienie o Walentym Kuczyńskim [1913 - 1990] s. 141 - 143; Grochowski A. Pamięci profesora Zbigniewa Folejewskiego s. 145-150; Grochowski A.: Polonista w Mandżurii. Czesław Bobolewski (1907-1993) s. 151-154.

362. NAUCZYCIELE tajnego nauczania w Warszawie w latach 1939-1944. Spis osób. Oprac. Maria Śliwińska. Wyd. 2. Warszawa 2002 Wydaw. Szkolne i Pedagog. ss. 104. Zwiazek Nauczycielstwa Polskiego. Zarząd Okręgu Mazowieckiego, Okręgowa Kom. Hist. w Warszawie.

Wyd. 1. 1995.

363. OCALIĆ od niepamięci. Praca zbiorowa. Pod red. Jolanty Szablickiej-Żak. Kraków 2002 Impuls ss. 103, nlb. 1, il.

Treść: Szablicka-Żak J.: Slowo wstepne s. 7-10; Szulakiewicz Władysława: Stanisław Franciszek Tync (1904-1964). Szkic portretu historyka oświaty i wychowania s. $11-26$; Semków Jerzy: Wincenty Ostrowski (1904 - 1969). Współtwórca teorii - oświaty dorosłych i pracy kulturalno-oświatowej s. 27 -38; Matuszycki Alojzy: Marian Wachowski (1903 - 1970). Prekursor andragogiki s. 39-60; Stasieńko Teresa: Stefan Kaczmarek (1909 - 1984). 
Nauczyciel nauczycieli s. 61-70; Dębska Urszula: Marian Kulczycki (1924-1995). Niezapomniany romantyk myśli psychologicznej s. 71-84; Szablicka-Żak J.: Zofia Maresz (1926-1995). Bogactwo i siła ducha w kruchej postaci s. 85-92; Szablicka-Żak J.: Mirosława Chamcówna (1919-2000). Historyk oświaty i nauki s. 93 - 102.

Biografie pracowników Instytutu Pedagogiki Uniwersytetu Wrocławskiego.

364. REKTORZY państwowych wyższych uczelni w Łodzi 1945-2000. Unjwersytet Łódzki, Politechnika Łódzka, Akademia Medyczna, Wojskowa Akademia Medyczna, Akademia Sztuk Pięknych, Akademia Muzyczna, Państwowa Wyższa Szkoła Filmowa, Telewizyjna i Teatraina, Wyźsze Seminarium Duchowne. Red. Elżbieta Paradowska. Łódź 2002 Łódzkie Tow. Nauk. ss. 332 , i1.

365. ROZYNEK Józef, Ziółkowski Józef J[ulian]: Doktorzy honoris causa Uniwersytetu Wroclawskiego 1948 - 2002. Wyd. 2 popr. i uzup. Wrocław 2002 Wydaw. Uniw. Wrocławskiego ss. 330, nlb. 1, il. Acta Universitatis Wratislaviensis. No 2412.

Wyd. 1. 1993.

366. SŁOWNIK biograficzny pracowników CIWF [Centralnego Instytutu Wychowania Fizycznego] i AWF [Akademii Wychowania Fizycznego]. T. 3. Pod red. Kajetana Haadzelka i Andrzeja Mazura. Warszawa 2002 AWF ss. 70, nlb. 1, il. Akad. Wychowania Fizycznego J. Piłsudskiego w Warszawie.

\section{T. 1. 2000 .}

367. ZAJAC Stanisław: Ocalić od zapomnienia. Pracownicy naukowi oraz absolwenci-wychowankowie Uniwersytetu Jagiellońskiego - oficerowie Wojska Polskiego ofiary zbrodni stalinowskiego NKWD - 1940 r. Kraków 2002 Inst. Teol. Księży Misjonarzy ss. 256, il.

\section{Poszczególne biografie}

\section{Amicinus Jan}

368. Prokop Krzysztof Rafal: Jan Amicinus z Krakowa (zm. 1526), biskup laodycejski, prepozyt u św. Mikołaja (1502-1526), rektor i wicekanclerz Akademii Krakowskiej. W: Studia z dziejów kościoła św. Mikołaja w Krakowie. Pod red. Zdzisława Klisia. Kraków 2002 s. $29-45$.

\section{Bernahrd Józef}

369. KORZENIOWSKA Wiesława: Józef Bernhard - nauczyciel chorzowskiego gimnazjum (1896-1942). Zesz. Chorzowskie. T. 6: 2001 [druk.:] 2002 s. $211-218$, Zsfg.

\section{Bliziński Wacław}

370. KESZKA Sławomir: Inicjatywy społeczno-oświatowe ks. prałata Wacława Blizińskiego w Liskowie w latach 1900-1925. Kaliskie Studia Teol. [T.] 1: 2002 s. 217-233, Zsfg.

\section{Budniakiewicz Edmund}

371. SUSZEK Iza, Wolska Krystyna: Edmund Budniakiewicz [1896 - 1976] - dyrektor Szkoły Podstawowej w Janowcu w latach $1945-1966$. Notatnik Janowiecki. Nr 12: 2002 s. $188-198$.

\section{Bujwidowa Kazimiera}

372. DORMUS Katarzyna: Kazimiera Bujwidowa 1867-1932. Życie i działalność społeczno-oświatowa. Kraków 2002 Secesja ss. 188, nlb. 2, tabl. 12, il. Tow. Miłośn. Historii i Zabytków Krakowa. Biblioteczka Krakowska. Nr 144.

Zawiera także bibliografię prac K. Bujwidowej. 


\section{Charłampowicz Konstanty}

373. HAWR YLUK Jerzy: Konstanty Charłampowicz [1870 - 1932] - historyk Cerkwi i oświaty. Przegl. Prawostawny. [R. 18]: 2002 nr 7 s. 31-32.

\section{Frąckiewicz Henryk}

374. PAWLOWSKI Franciszek: Henryk Frąckiewicz [1912-2001]. Stężyca 2002 PWHU „M-Press” ss. 46, il. Tow. Przyj. Stężycy.

\section{Gniazdowski Włodzimierz}

375. GÓRNIAK Janina: Profesor „Dziadek” (wspomnienia). Włocławek 2002 Bibl. Publ. ss. 53, nlb. 1, il. Wrocławianie.

Wlodzimierz Gniazdowski (1906-1980).

\section{Jotejko Józefa}

376. MAJCHRZAK-Mikuła Joanna: Józefa Jotejko [ur. 1866] - prekursorka szkolnictwa specjalnego. Piotrkowskie Studia Pedagog. T. 9: 2001 s. 373-381.

\section{Kaczmarek Szczepan}

377. SKORUPSKA Elżbieta: Szczepan Kaczmarek (1884-1939). Polityk, działacz społeczny, pedagog. Grabonoskie Zapiski Regionalne. [T.] 10: 2002 s. 21 - 48.

\section{Kąsinowski Bronisław}

378. ERGETOWSKI Ryszard: Związi Bronisława Kąsinowskiego [1861 - 1918] z wrocławskim i krakowskim uniwersytetem. Rozprawy z Dziejów Oświaty. T. 41: 2002 s. $129-149$.

\section{Kleczeński Aleksander}

379. PUDŁOCKI Tomasz: Sylwetki przemyskich nauczycieli filologów. Aleksander Kleczeński [1876-1924]. Roczn. Przemyski. T. 38: 2002 z. 1 s. $111-115$.

\section{Kolendo Maria}

380. TOMCZONEK Zofia: Maria Kolendo - pedagog i działacz społeczny (1894-1980). Biatostocczyzna. [R. 14]: 1999 nr 4 s. $135-142$.

\section{Komeński Jan Amos}

381. MEISSNER Andrzej: Miejsce Jana Amosa Komeńskiego w polskich badaniach po II wojnie światowej (w 330. rocznicę śmierci). Roczn. Komisji Nauk Pedagog. T. 55: 2002 s. 35-44, sum.

382. Wróblewska Teresa: Jan Amos Komensky (1592-1670) und sein Beitrag zur Frühschulerziehung. Piotrkowskie Studia Pedagog. T. 9: 2001 s. 457-462.

\section{Kramsztyk Stanisław}

383. DORMUS Katarzyna: Stanisław Kramsztyk - popularyzator, pedagog, erudyta (1841 - 1907). Rozprawy z Dziejów Oświaty. T. 41: 2002 s. $151-191$.

\section{Krotoski Kazimierz Michał}

384. KIJAWSKA Maria: Kazimierz Michał Krotoski (1860 - 1937). Pedagog - historyk - publicysta. W: Dzieje polityczne, kultura, biografistyka. Studia z historii XIX i XX wieku ofiarowane prof. Zbigniewowi Dworeckiemu. Pod red. Lecha Trzeciakowskiego i Przemysława Matusika. Poznań 2002 s. $337-344$.

\section{Krzyżanowski Antoni}

385. MARCZUK Józef: Antoni Krzyżanowski jako lubelski nauczyciel i wzorowy dyrektor gimnazjalny (1884-1939). Przegl. Hist.-Oświat. R. 45: 2002 z. 1/2 s. $121-127$. 


\section{Kwiatkowski Wincenty}

386. KSIADZZ rektor Wincenty Kwiatkowski [1892 - 1972] - uczony i człowiek. W trzydziesta rocznicę śmierci. Red. Zygmunt Falczyński. Warszawa 2002 Wydaw. UKSW ss. 215, il.

Z treści: Falczyński Z: Wprowadzenie s. 13-15; Gogolewski Tadeusz: Życie i dzieło ks. prof. Wincentego Kwiatkowskiego s. 17-25; Falczyński Z.: Profil naukowo-dydaktyczny ks. prof. Wincentego Kwiatkowskiego s. 26-40; Bartnicki Roman: Ks. Profesor Wincenty Kwiatkowski - rektor walki o przetrwanie ATK [Akademii Teologii Katolickiej w Warszawie] s. 41-48; Falczyński Z.: Kalendarium działalności J.M. ks. prof. Wincentego Kwiatkowskiego, rektora ATK (1956-1965) s. 49-67; Dybczyńska Kazimiera: Moje wspomnienia o księdzu prof. dr Wincentym Kwiatkowskim, wieloletnim Rektorze ATK s. 173-178; Hladowski Władysław: Na drogach wskazanych przez Profesora s. 179-184; Tabaczyński Wojciech: W trzydziesta rocznice śmierci ks. prof. Wincentego Kwiatkowskiego s. 185-189; Gogolewski T.: Wspomnienie o ks. prof. W. Kwiatkowskim, po uzydziestu latach od jego śmierci s. 190-193; Jankowski Augustyn (Bogdan): Rektor Wincenty Kwiatkowski (zm. 1972) - jak dziś go pamiętam i za co szczególnie cenię? s. 195-197; Romaniuk Kazimierz: „Ks. prof. W. Kwiatkowski trwa w mojej pamięci...” s. 198-201; Olejnik Stanislaw: Wincenty Kwiatkowski, profesor, kapłan, człowiek s. 202-208; Urbański Stanisław: Wspomnienie o ks. Rektorze W. Kwiatkowskim s. $209-211$.

\section{Leszczyński Jan Nepomucen}

387. FRACKIEWICZ Joanna: Jan Nepomucen Leszczyński [1806-1886] i jego instytut na Świętojerskiej. Przegl. Hist.-Oświat. R. 45: 2002 z. 1/2 s. $109-119$.

Założyciel i dyrektor prywatnej szkoly realnej w Warszawie w 1. 1843-1877.

\section{Lepkowski Józef Aleksander}

388. OSTROWSKI Janusz A.: Józef Aleksander Łepkowski (1826 - 1894) - twórca uniwersyteckiego gabinetu archeologicznego. Alma Mater. Nr 41: 2002 s. 22-24.

\section{Majorek Czesław}

389. KRUKOWSKI Jan: Czesław Majorek (1938-2002). Studia Hist. R. 45: 2002 z. $3 / 4$ s. $353-354$.

\section{Marciniak Sylwester}

390. GERTYCH Mirosław: Ksiadz Sylwester Marciniak [1906 - 1980] - wychowawca młodzieży w Lesznie. Kronika Wielkopolski. [R. 28]: $2000 \mathrm{nr} 4$ s. $91-96$.

\section{Michalak Stefan}

391. MACHALIŃSKI Zbigniew: Stefan Michalak [1909 - 1947] - lekarz, podróżnik, organizator Akademii Medycznej w Gdańsku. Gdańsk 2001 Marpress ss. 98, nlb. 2, il.

Rec.: Bednarski Zenobiusz M[ichal], Archiwum Hist. i Filoz. Med. T. 65: 2002 z. 4 s. 507-509.

\section{Mrozowska Kamilla}

392. BARTNICKA Kalina: Kamilla Mrozowska (28 I 1917 - 2 V 2002). Rozprawy z Dziejów Oświaty. T. 41: 2002 s. 3-5.

393. DYBIEC Julian: Kamilla Mrozowska (1917-2002). Studia Hist. R. 45: 2002 z. 3/4 s. $351-352$.

\section{Pobereszko Franciszek}

394. PACZKOWSKI Stefan: Franciszek Pobereszko (1916-1999) - „Człowiek ze Służewa”. Zapiski Kujawsko-Dobrzyniskie. T. 16: 2001 s. 229-232.

Zasłużony dla Kujaw i Pomorza nauczyciel, publicysta, poeta, malarz.

\section{Poliński Michał}

395. BARTNICKA Kalina: Człowiek uniwersytetu: Michał Pełka-Poliński (1783 - 1848). Kariera akademicka ubogiego szlachcica na Uniwersytecie Wileńskim. Cz. 1. Rozprawy z Dziejów Oświaty. T. 41: 2002 s. $75-91$. 


\section{Preibisz Bronisław}

396. PIWOWARSKI Jerzy: Bronisław Preibisz (1879 - 1929). Życie i twórczość współorganizatora poznańskiej Szkoły Sztuk Zdobniczych. Częstochowa 2002 Wydaw. WSP ss. 86, nlb. 1, il. Wyższa Szkoła Pedagog. W Częstochowie.

\section{Rogal Witold}

397. WOJCIECHOWSKA Bogna: Nasz pan dyrektor Witold Rogal [1910-2000]. Opowieść o twórcy Państwowego Liceum Muzycznego w Poznaniu. Poznań 2001 Staraniem Anastazji z Rogalów Laskowskiej oraz autorki; Vis ss. 162, nlb.1, tabl. 24, il., nuty.

\section{Sikora Franciszek}

398. KOWALCZYK Malgorzata: Franciszek Sikora (1905 - 1977) - nauczyciel, inspektor, kurator oświaty. Mragowskie Studia Humanist. T. 3: 2001 s. 67-78, Zsfg.

\section{Skwarczyński Adam}

399. KRYŃSKA Elwira J[olanta]: Trwałe wartości ideologii wychowawczej Adama Skwarczyńskiego [1886-1934]. Przegl. Hist.-Oświat. R. 45: 2002 z. 3/4 s. $141-155$.

\section{Sośnicki Kazimierz}

400. GAJDAMOWICZ Halina: Wychowanie obywatelsko-państwowe Kazimierza Sośnickiego [1883-1976]. Przegl. Hist.-Oświat. R. 45: 2002 z. 3/4 s. $131-140$.

\section{Stipal Stefania}

401. WOJTKIEWICZ Małgorzata: Harcmistrzyni Stefania Stipal [1903 - 2000] - druhna Luna. Wspomnienia o byłej komendantce Lwowskiej Choragwi Harcerek. Warszawa $2000 \mathrm{Zw}$. Harcerstwa Rzeczypospolitej ss. 135, il.

\section{Talar Antoni}

402. PUDŁOCKI Tomasz: Sylwetki przemyskich nauczycieli filologów. Antoni Talar [1874-1923]. Roczn. Przemyski. T. 38: 2002 z. 1 s. $107-110$.

\section{Tomaszewski Piotr}

403. RULKA Kazimierz: Ks. Piotr Tomaszewski [1908 - 1967] jako wychowawca. Ateneum Kapt. T. 138: 2002 z. 1 s. $119-130$.

\section{Waga Jakub}

404. JAKUB Waga [1800 - 1872] - pedagog i uczony. Pod red. Wandy Grębeckiej. Łomża 2001 ETN ss. 142, il. Lomżyńskie Tow. Nauk. im. Wagów.

Materiały z sesji, Łomża, $12-13$ X 2000 r.

Z treści: Dobroński Adam: Jakub Waga - tomżanin s. 11-29; Wincenciak Witold: Działalnośc pedagogiczna Jakuba Wagi (1800-1872) s. 91 - 100; Waga Jan Maciej: Wspomnienia rodzinne po przodkach (próba ustalenia dziejów rodziny) s. 103-107; Szymańska Wieslawa: Ślady kultury materialnej po rodzinie Wagów s. 109-119.

\section{Wycech Czesław}

405. PIOTROWICZ Dariusz: Działalność oświatowa i społeczno-polityczna Czesława Wycecha do 1939 r. W: Dzieje i przyszłość polskiego ruchu ludowego. T. 1: Od zaborów do okupacji (1895-1945). Red. nauk. Arkadiusz Kołodziejczyk, Waldemar Paruch. Warszawa 2002 s. 645-660.

\section{Wyczółkowski Leon}

406. BEDNARSKI Tadeusz Z[ygmunt]: Leon Wyczółkowski [1852-1936] jako pedagog. W 150-lecie urodzin artysty. Alma Mater. Nr 41: 2002 s. $27-29$.

Lata $1905-1930$. 


\section{DZIEJE OŚWIATY POZASZKOLNEJ}

\section{Oświata dorosłych}

407. CENTRUM Kształcenia Ustawicznego im. Stanisława Staszica w Mińsku Mazowieckim w latach 1977-2002. Tradycje i teraźniejszość. Zespól red. Jan Wiśniewski [i in.]. Mińsk Mazowiecki-Radom 2002 Inst. Technologii Eksploatacji ss. 219, nlb. 2, il.

$\mathrm{Z}$ treści: Trojanowski Jacek: Oświata doroslych $\mathrm{w}$ okresie międzywojnia $\mathrm{z}$ uwzględnieniem powiatu Mińsk Mazowiecki s. 11-24; Trojanowski J.: Szkola dla dorosłych w powiecie Mińsk Mazowiecki w latach 1945-1977 s. 25 -63; Wiśniewski J.: Centrum Ksztalcenia Ustawicznego w latach 1977 - 2001 s. 65 -94; Sawicka Hanna: Nasze doświadczenia s. 95-126; Wspomnienia i opinie. Oprac. J. Wiśniewski s. 127-161; Wiśniewski J.: ln memoriam s. 163-170; Zalączniki s. 197-212.

\section{Biblioteki}

408. GEBOEYŚ Zdzisław: Biblioteka szkoły średniej w Mickunach (Republika Litwy) w latach 1990 - 1999. Prace Nauk. UŚ w Katowicach. Nr 2045: Studia Bibliologiczne. T. 14: 2002 s. 86-102, rez., sum.

409. GULIŃSKA Grażyna: Ideologiczne selekcje księgozbiorów w Polsce w latach 1944 - 1956 ze szczególnym uwzględnieniem bibliotek szkolnych Kielc. Kieleckie Studia Bibliol. [T.] 6: 2001 s. $49-59$, sum.

410. OLSZÓWKA Małgorzata: Polskie księgozbiory pedagogiczne w województwie śląskim w latach 1922 - 1939. Stan badań. Prace Nauk. UŚ w Katowicach. Nr 1978: Studia Bibliologiczne. T. 13: 2001 s. $106-111$, rez., sum.

411. POMES Kinga, Stępień Bogdan: Biblioteka Towarzystwa Oświaty „Mrówka” w Łańcucie w latach 1868-1914. Prace Hist.-Archiw. T. 12: 2002 s. 229-234.

412. SZULC Jolanta: Biblioteki uczelni kościelnych w Polsce - między tradycją a współczesnościa. Fides. [R. 8]: $2002 \mathrm{nr} 1$ s. $32-53$.

413. WAŁEK Bożena: Biblioteki szkół ludowych w Galicji doby autonomicznej. Prace Nauk. US w Katowicach. Nr 1978: Studia Bibliologiczne. T. 13: 2001 s. 46-61, rez., sum.

\section{DZIEJE RUCHU NAUCZYCIELSKIEGO}

\section{Opracowania ogólne}

414. ENCYKLOPEDIA Związu Nauczycielstwa Polskiego województwa śląskiego. Cz. 1. Kom. red. Irena Anczarska-Smandek [i in.]. Katowice-Rybnik 1998 ZNP. ZOŚ; Agencja Wydawnicza „Bit Poligraf" ss. 163, nlb. 5. Zw. Nauczycielstwa Pol. Zarząd Okręgu Sląskiego w Katowicach.

Toź. Cz. 2. Katowice 2000 ss. 272.

Toż. Cz. 3. Katowice 2002 ss. 359.

$\mathrm{XX} w$.

415. GRZES Bolesław: Zwiazki nauczycielskie a reformowanie szkolnictwa na ziemiach polskich w XX wieku. Cz. 2: Zwiazki nauczycielskie wobec reformowania ustroju szkolnego w Polsce w latach 1919-1939. Przegl. Hist.-Oświat. R. 45: 2002 nr 1/2 s. 53-69.

Cz. 1. Tamże. R. 44: $2001 \mathrm{nr} 1 / 2$. 
416. MACISZEWSKI Seweryn Władyslaw: Kartka z dziejów kryzysu w ZNP (1937 - 1938). Wyd. Jarema Maciszewski. Rozprawy z Dziejów Oświaty. T. 41: 2002 s. 243-253.

Wspomnienia komisarycznego kuratora Zwiazku Nauczycielstwa Polskiego.

417. SYCHOWICZ Krzysztof: „Za” czy ,przeciw”. Biul. IPN. Nr 12: 2002 s. $78-82$.

Działalność i struktury nauczycielskiej „.Solidarności” w 1. 1980-1981.

418. WOŹNIAK Erwin: Dziedzickie Koło Polskiego Towarzystwa Pedagogicznego. Kalendarz Cieszyński. [R. 17]: 2001 [druk.:] 2000 s. $70-77$.

Na Śląsku Cieszyńskim w 2. pol. XIX - XX w.

419. ZWIAZZEK Nauczycielstwa Polskiego na Lubelszczyźnie w latach 1986-2000. Pod red. Jerzego Doroszewskiego. Lublin 2002 ZNP ss. 224, il. Zw. Nauczycielstwa Pol.

Z ureści: Działalność Okręgów Zwiazku Nauczycielstwa Polskiego na Lubelszczý́nie w latach 1986-1999: Kamińska Anna: Okręg Bialskopodlaski s. 13 - 18; Kiernikowski Pawel, Pyszko Stanisław: Okręg Chelmski s. 19-36; Bobowska Grażyna, Tylus Maria, Wladzińska Sabina: Okręg Lubelski s. 37-90; Bury Marian: Okręg Zamojski s. 91-104; Materialy do dziejów Zwiazku Nauczycielstwa Polskiego na Lubelszczyźnie; Kaznowski Kazimierz: Działalność ekonomiczno-usługowa Zwiazku s. 127 - 152; Doroszewski J.: Wydawnictwa zwiazkowe na Lubelszczyźnie w latach 1920 - 1998 s. 153 - 168; Kiernikowski Pawel, Pyszko Stanisław, Marczuk Józef: Zasłużeni dzialacze ruchu związkowego na Lubeszczyźnie s. 169 - 205; Jończyk Anna: Sklady osobowe okręgowych wladz związkowych na Lubelszczyźnie w latach 1986-2000 s. 207-215.

\section{Pamiętniki nauczycieli}

420. BOCZARSKA Bożena: Włocławska ballada. Włocławek 2002 Lega ss. 162, nlb. 1, il. Wspomnienia włocławskiej nauczycielki z lat 1945-2000.

421. DRZEWIECKI Władysław: Moje życie. Pamiętnik nauczyciela i społecznika. Wstępem poprzedził Mirosław Krajewski; oprac. red. Iwona Zielińska. Włocławek-Wymyślin 2002 Wyższa Szkoła Humanist.-Ekonom. ss. 181, nlb. 3, il.

Wspomnienia z dzieciństwa w Skępem, nauki w Seminarium Nauczycielskim w Wymyślinie, udziale w kampanii wrześniowej i pobycie w oflagach oraz przedwojennej i powojennej działalności pedagogicznej i spolecznej.

422. DZIDUSZKO Władysław: Z obcymi i u swoich. Cz. 1. Bieszczad. [T.] 8: 2001 s. $206-257$.

Toż. Cz. 2. Tamże. [T.] 9: 2002 s. $169-236$. AK.

Okupacyjne wspomnienia kierownika Szkoły Powszechnej w Ustrzykach Dolnych, członka tamtejszej placówki

423. GUŹDZIO Mieczysław: Moje życie. Wspomnienia. Red. i przedm. Tadeusz Stolarski. Włoszczowa 2001 Nakł. autora pod patronatem Włoszczowskiego Tow. Krzewienia Kultury ss. 160, nlb. 2, il.

Wspomnienia harcerza i nauczyciela obejmujace dzieciństwo w przedwojennym Przemyślu, lata okupacji sowieckiej i niemieckiej oraz powojenna pracę pedagogiczną (glównie we Wloszczowej).

424. HOLZMAN Helene: To dziecko musi przeżyć. Niezwykłe pamiętniki Helene Holzman. Oprac. Reinhard Kaiser i Margarete Holzman; z niem. przeł. Maria Przybyłowska i Eliza Borg. Warszawa 2002 Fakty ss. 222, nlb. 2, tabl. 32, il., mapa.

Okupacyjne wspomnienia litewskiej Żydówki, nauczycielki w gimnazjum niemieckim w Kownie.

425. KOŃCZYK Romuald Marian: Odkurzone z pamięci. (Dzieje powojennej oświaty na wspomnienia jednego człowieka przełożone). Sandomierz-Ożarów 2002 Myjakpress; Miej.-Gminny OK ss. 254, nlb. 2. Biblioteka Miesięcznika „Ożarów” Ożaroviana. [T.] 1.

426. KURPIEWSKI Tadeusz: W służbie Mazowsza i Plocka. Wstęp Tadeusz Kołodziejak. Płock 2002 Komisja Hist. Zw. Nauczycielstwa Pol. przy Zarządzie Oddz.; Korepetytor ss. 116, il.

Pamiętnik nauczyciela, dzialacza społecznego i sportowego obejmujacy lata nauki szkolnej od 1944 r., pracę w kolejnych placówkach oświatowych (głównie w Płocku), ponadto zawiera wspomnienia współpracowników i uczniów autora. 
427. LEŚSIEWICZ Wiktor: Polska! Oprac. i wstępem opatrzył Alfred Siama. Kronika Wielkopolski. [R. 27]: 1999 nr 1 s. $93-100$.

Wspomnienia nauczyciela ze Skoraszewic z okresu od XI 1918 do lata 1919 r.

428. LUBERTOWICZ Zygmunt: Pół wieku polskiej szkoły i walki. Wspomnienia z lat 1890 - 1945. Kraków 2002 Miniatura ss. 192.

Wspomnienia z lat nauki w Nowym Targu i Krakowie, studiów na UJ oraz pracy nauczycielskiej i społecznej w Nowym Targu i Bielsku.

429. MAGURA Emilia Maria: Miłość Emilii. Kraków 2002 Fundacja Studium Okręgu AK Kraków ss. 377, il.

Wspomnienia nauczycielki (ur. 1921), absolwentki Prywatnego Seminarium Zofii Strzałkowskiej z pracy nauczycielskiej w międzywojennej Łodzi, oraz lat okupacji w Krośnie.

430. WOJCIECHOWICZ Antoni: Wspomnienia, wspomnienia. Moje dziecięce lata w Wilnie. Giżycko 2002 Nakł. autora ss. 206, nlb. 1, il.

Wspomnienia z międzywojennego Wilna, lat okupacji na Wileńszczyźnie, oraz pracy nauczycielskiej w Giżycku.

431. ŻEBROK Jan: Pamiętnik śląskiego nauczyciela. Oprac., wstęp i indeksy Jadwiga Miękina-Pindur. Cieszyn 2002 Macierz Ziemi Cieszyńskiej ss. 207, il.

Pamiętnik żyjacego w l. 1883 - 1965 pedagoga, działacza społecznego, prezesa Zarządu Glownego Macierzy Szkolnej Ziemi Cieszyńskiej, opisuje pracę w szkołach Ślaska Cieszyńskiego, zmagania o polskość tych ziem i pobyt w obozie w Dachau.

\section{ORGANIZACJE MŁODZIEŻOWE}

432. ANDRYKIEWICZ Jan: Zwiazek Młodzieży Wiejskiej w latach $1957-1976$. Wyd. 3 popr. Warszawa 2002 Muzeum Historii Pol. Ruchu Ludowego ss. 117, nlb. 1, tabl. 8, il. MHPRL, Zakł. Historii Pol. Ruchu Ludowego NKW PSL, Stow. Pokolenia - Zarząd Krajowy. Biblioteka Muzeum Historii Polskiego Ruchu Ludowego.

Wyd. 1. Zielona Góra 1988.

433. BARAN Adam F.: Harcerstwo niepokorne i niezależne w ostatniej dekadzie PRL. Studia Rzeszowskie. T. 9: 2002 s. $231-247$.

Harcerski Ruch Liturgiczny, Krąg Instruktorów Harcerskich im. A. Małkowskiego, Niezależny Ruch Harcerski, Polska Organizacja Harcerska, ZHP-1918, Zwiazek Harcerstwa Rzeczypospolitej.

434. BILNIK Piotr: Początki skautingu w Częstochowie. Almanach Czestochowy. [T. 16]: 2001/2002 [druk.:] 2002 s. $85-99$.

Lata 1908 - 1918.

435. CHUDZIŃSKI Piotr: Zmierzając ku doskonałości. Historia Katolickiego Stowarzyszenia Młodzieży w zarysie - lata 1919-1951. Gniezno 2002 Gaudentinum ss. 199, nlb. 7, il. Biblioteczka KSM. Nr 64.

436. DOROSZEWSKI Jerzy: Życie organizacyjne młodzieży $w$ seminariach nauczycielskich w Polsce w latach 1918 -1937. Przegl. Hist.-Oświat. R. 45: 2002 z. 1/2 s. $71-91$.

437. [DWUDZIESTOPIECIOLECIE] 25-lecie Akademickiego Związku Sportowego. Księa pamiatkowa. Pod red. Wiesława Pięty i Stanisława Podobińskiego. Częstochowa 1998 Wydaw. WSP ss. 65, il. Wyższa Szkoła Pedagog. W Częstochowie.

438 HISTORIA Związku Harcerstwa Polskiego na ziemi kwidzyńskiej. Zesz. Kwidzyńskie Nr 2000 s. $57-133$.

Treść: Hawliczek Otton Henryk: Historia ZHP Kwidzyn od 1920 do 2000 roku s. 57-69; Hawliczek O. H. Kalendarium [i Komendanci Hufca Kwidzyn] s. 70-73; Tyniec Tadeusz: Pierwsze dni w Kwidzynie s. 74-77; Misiurewicz Bohdan: „Bylem wśród niepokornych” s. 78-79; Kremky Elżbieta: Drużyny żeńskie s. 80-81; Jaskóla 
Teresa: Moje harcerstwo s. 82-86; Piecuch Adam: Kwidzyński epizod... s. 87-89; Zickau Witold: Pamiętajcie, że zdarzyło się to ponad 50 lat temu!... s. 90 -91; Bagiński Tadeusz: Krótki życiorys harcerski s. 92-93; Ludwikowski Hieronim: Wspomnienie s. 94-95; Tyniec T.: „Sulima” s. 96-99; Tyniec T.: „Matecznik” s. 100-111; Tyniec T.: Obóz w Kleczewie s. 112-115; Tyniec T.: Pływak s. 116-120; Dudulewicz Zofia: Moja harcerska droga. s. $121-126$.

439. KREZŻEL Janusz: Młodzieżowe organizacje niepodległościowe na terenie c.k. Gimnazjum Państwowego w Mielcu $1908-1918$ (zarys). Roczn. Mielecki. T. 5: 2002 s. 87-118.

440. MACIEJEWSKI Jan: Z dziejów harcerstwa kaliskiego (1911/12 - 1939). Kalisz 1998 Fundacja Przyj. Kalisza ss. 174, il.

Rec.: Alexander Krystyna, Kronika Wielkopolski. [R. 28]: 2000 nr 2 s. 136-138.

441. MAGURA-WITKOWSKA Maria: Album pamięci pokoleń. Kraków 2002 Nakł. Fundacji Studium Okręgu AK ss. 247, tabl. 1, il., nuty.

Księga pamiątkowa Zwiazku Harcerstwa Polskiego hufców: Jasło im. Rodziny Madejewskich i Krosno im. Jana i Stanisława Magurów.

442. MATERIAŁY do historii skautingu w Tarnowie 1911 - 1912. [Wyd.] Marek Popiel. Tarnów 2002 Harcerska Pracownia Archiw.-Nauk. ss. 52.

443. MATUSZAK Tomasz: Harcerze - Kawalerowie Krzyża i Medalu Niepodległości. Biul. Wojsk. Służby Archiw. Nr 24: 2001 [druk.:] 2002 s. $117-128$.

Ustanowione w $1930 \mathrm{r}$.

444. NADOLNY Anastazy: Związek Harcerstwa Polskiego w Hamburgu po II wojnie światowej. Studia Pelplińskie. T. 33 [wyd. specjalne]: 2002 s. 475-479.

445. [OSIEMDZIESIAT PIEĆC] 85 lat harcerstwa czempińskiego 1913-1998. Opracowanie zbiorowe. Pod red. Henryka Florkowskiego. Czempiń 2002 Stow. Przyj. i Sympatyków Ziemi Czempińskiej ss. 176, il.

Z treści: Hirowski Stefan, Świątkiewicz Józef: Drużyna Harcerzy im. Stefana Batorego w Czempiniu w latach 1913-1918 s. 14-15; Florkowski H.: Czempińskie pokolenie powstańców s. 16-18; Przybylski Marian: Lista uczestników powstania wielkopolskiego 1918 - 1919 zamieszkalych na terenie Czempinia $i$ okolicy $w$ latach 1918 - 1998 s. 19 - 29; Gintrowski Edward, Hirowski S., Świątkiewicz J.: Okres międzywojenny s. 30 - 36; Hirowski S., Swiąkiewicz J., Florkowski H.: Harcerze czempińscy w czasie okupacji hitlerowskiej (1939-1945) s. 37-43; Gintrowski E., Hirowski S., Walorek Wiktor: Harcerstwo w Czempiniu w latach $1945-1950$ s. 44 - 51; Florkowski H.: Organizacja Harcerska Polski Ludowej (1950 - 1956) s. 52 - 54; Gintrowski E., Hirowski S., Walorek W.: Z działalnosci harcerstwa czempińskiego w latach 1956-1984 s. 55-73; Gintrowski E.: Obozy harcerzy czempińskich w okresie PRL s. 74 - 79; Lewandowicz Zbigniew: Szczep Drużyn Związu Harcerstwa Polskiego im. Szarych Szeregów przy Szkole Podstawowej w Czempiniu w latach $1995-1997$ s. 80-84; Swiatkiewicz J.: Miejsca pamięci hm. Floriana Marciniaka na Ziemi Kościańskiej s. 85 - 90; Florkowski H.: Sylwetki czempińskich harcerzy s. 91 - 141; Wspomnienia s. $145-175$.

446. PAŁYS Piotr: Akademickie Stowarzyszenie Łużyczan Studentów Wyższych Uczelni Wrocławia „Lusatia” 1947-1953. Slaski Kwart. Hist. Sobótka. R. 47: 2002 nr 4 s. 469-483, Zsfg.

447. PATER Daniel: Żydowski Akademicki Ruch Korporacyjny w Polsce w latach 1898 - 1939. Dzieje Najnowsze. R. 34: 2002 nr 3 s. 3-20, sum.

448. PIETRZYKOWSKI Marian, Pilarczyk Zbigniew: 45 lat pracy Komisji Historycznej Choragwi Wielkopolskiej ZHP 1957-2002. Poznań 2002 Staraniem aut. członków KH ss. 129, tabl. 33, il.

449. RASZKA Kazimierz: Zwiazek Młodzieży Socjalistycznej na Ziemi Cieszyńskiej (1957 - 1976). Cieszyn 2002 Interfon; Koło Pow. Stow. „Pokolenia" ss. 71, il.

450. RYBSKI Bogusław, Wojtycza Janusz, Wojtycza Krzysztof: Materialy do historii Krakowskiej Choragwi Harcerstwa w latach 1956-1959. Kraków 2000 F.H.-U. [Firma Handlowo-Usługowa] Grzegorz Słomczyński ss. 92, il. Zw. Harcerstwa Pol. Komenda Choragwi Krakowskiej im. T. Kościuszki. Komisja Hist. 
451. SADOWSKI Jan: Kronika drużyny harcerskiej. 7 Suwalska im. Adama Mickiewicza z lat 1927 - 1928. Pruszków 2002 Ulmak ss. 107, nlb. 1, tabl. 8, il.

452. SAMSONOWICZ Zdzisław: Wspomnienia o Straży Akademickiej Politechniki we Wrocławiu. Wrocław 2002 Oficyna Wydawnicza Politech. Wrocławskiej ss. 112, il.

Z I. $1944-1956$.

453. SKOTNICKI Wojciech Jerzy: Harcerstwo męskie we Włocławku w latach 1911 - 1945. Toruń 2002 Zapolex-Media ss. 380, il., rès., sum.

454. STRZEMBOSZ Tomasz: Harcerstwo polskie w latach 1944 - 1989. W: Ziemia Zawkrzeńska. T. 5. Praca zbior. pod red. Ryszarda Juszkiewicza. Mława 2001 s. 122-134.

455. ŚLADAMI lilijki w grodzie Kopernika. Pod red. Lesława J. Welkera. Toruń 2002 Wydaw. Adam Marszałek ss. 191, nlb. 1, tabl. 10, il.

Z treści: Welker L. J.: Wstęp s. 7 -10; Durczewski Jaromir: Skauci-harcerze Wielkiego Pomorza w walce o niepodleglość Polski 1914 - 1921 (zarys problematyki - stan badań) s. 11-18; Jankowski Jan: Rozwój i działalność harcerstwa męskiego w Toruniu w latach 1920 - 1939 s. 19 - 42; Jankowski J.: Harcerstwo żeńskie w Toruniu w okresie międzywojennym s. 49 - 60; Jankowski J.: Ruch przyjaciól harcerstwa w Toruniu s. 61 - 68; Durczewski J.: Pogotowie harcerskie Choragwi Pomorskiej ZHP (geneza - założenia - realizacja) s. 69-86; Durczewski J.: Być czlowiekiem to wciaż przezwyciezzać siebie - harcerska droga ks. phm. Stefana Wincentego Frelichowskiego s. 87-100; Welker L. J.: Harcerska mogiła w Olku s. 101 - 104; Lista strat harcerstwa toruńskiego w latach wojny 1939-1945 s. $105-108$; Welker L. J.: Szkic do historii harcerstwa w Toruniu w latach 1945-1950 s. 109-128; Aneksy s. 163-190.

456. Z NAJNOWSZEJ historii kultury fizycznej w Polsce. T. 5: Prace naukowe Letniej Szkoły Historyków Kultury Fizycznej. Pod red. Bernarda Woltmanna. Gorzów Wlkp. 2002 PTNKF. Oddz. ss. 650. Pol. Tow. Nauk. Kultury Fizycznej. Sekcja Historii KF i Oddz. w Gorzowie Wlkp., Inst. Wychowania Fizycznego Poznańskiej AWF w Gorzowie Wlkp.

Z treści: Małolepszy Eligiusz: Kultura fizyczna w działalności polskich wiejskich organizacji młodzieżowych w Drugiej Rzeczypospolitej s. 173-181; Krawczyk Magdalena: Trudności szkolnego wychowania fizycznego w województwie rzeszowskim w latach $1944-1949$ s. 363 -372; Nowak Leonard: Stan badań nad wychowaniem fizycznym i sportem w szkolnictwie podstawowym, średnim, ogólnokształcącym i zawodowym w Polsce w latach 1945-2000 s. 423-429; Szyszkowski Piorr: Działalność Akademickiego Zwiazku Sportowego przy Akademii Podlaskiej w Siedlcach (1969-2000) s. 443 - 449; Pięta Wiesław: Akademicki Zwiazek Sportowy w Częstochowie w Trzeciej Rzeczypospolitej (1989-2000) s. 507-514; Nowacka Małgorzata: Kształcenie nauczycieli wychowania fizycznego w Kolegium Nauczycielskim i w Państwowej Wyzzzzej Szkole Zawodowej w Lesznie w latach 1992 - 2001 s. 529-543; Malinowska Irmina Wioleta: Wychowanie fizyczne i sport w polskich szkołach na Wileńszczyźnie w latach 1945 - 1989 s. 573 - 581; Pieczyński Przemysław: Stowarzyszenia młodzieżowe działajace w zakresie kultury fizycznej na terenie Północnej Francji (1910-1940) s. 583-589;.

457. ZWIAZZEK Młodzieży Socjalistycznej wobec wydarzeń marcowych 1968 r. w świetle własnych dokumentów. [Wyd.] Włodzimierz Janowski. Teki Archiw. T. 6: 2001 s. 199-226. 